\title{
Trends of nutrients and metals in precipitation in northern Germany: the role of emissions and meteorology
}

\author{
Malte Lorenz $\mathbb{D} \cdot$ Matthias Brunke
}

Received: 19 November 2020 / Accepted: 19 April 2021 / Published online: 5 May 2021

(C) The Author(s) 2021

\begin{abstract}
We analyzed the precipitation chemistry for a maritime region in northern Germany (SchleswigHolstein) from 1997 to 2017 in order to reveal temporal and spatial patterns and to evaluate the role of meteorological factors relative to emission reductions in Germany and Europe. Therefore, we applied several statistical methods such as time series decomposition, principal
\end{abstract}

\section{Highlights}

- Decreasing long-term trends of $\mathrm{NH}_{4}{ }^{+}$and $\mathrm{SO}_{4}{ }^{2-}$ are strongly correlated with emission reductions of nitrogen and sulfur compounds in Germany.

- Decreasing long-term trends of $\mathrm{As}, \mathrm{Cd}, \mathrm{Cr}, \mathrm{Pb}, \mathrm{Ni}$, and $\mathrm{Zn}$ are caused by emission reductions related to the European Union and meteorological factors.

- Long-term trend of Hg shows no correlation to emissions in Europe but to NAO index and wind.

- In Northern Germany, the ratio of $\mathrm{NH}_{4}^{+} /$non-sea salt $\mathrm{SO}_{4}{ }^{2-}$ determines the spatial distribution as well as seasonal and long-term development of the $\mathrm{pH}$ in precipitation.

- The seasonal variation of $\mathrm{NH}_{4}{ }^{+}$concentrations in precipitation was mainly determined by seasonal variation of $\mathrm{NH}_{3}$ emissions and followed by precipitation volume.

M. Lorenz $(\bowtie) \cdot$ M. Brunke

Landesamt für Landwirtschaft, Umwelt und ländliche

Räume des Landes Schleswig-Holstein, Abteilung

Gewässer, Dezernat Fließgewässerökologie, Hamburger

Chaussee 25, Flintbek 24220, Germany

e-mail: mail@malte-lorenz.de

M. Brunke

Landesamt für Umwelt Rheinland-Pfalz, Abteilung

Gewässerschutz, Kaiser-Friedrich-Straße 7, Mainz 55116,

Germany component, and redundancy analysis. We extracted two main groups: (i) a marine group $(\mathrm{Cl}, \mathrm{Na}, \mathrm{Mg})$ that was related to natural processes like sea spray input and (ii) an anthropogenic group $(\mathrm{Pb}, \mathrm{Cd}, \mathrm{As}, \mathrm{Zn}$, and nitrogen species) with a terrestrial subgroup ( $\mathrm{Fe}, \mathrm{Al}, \mathrm{Mn})$, which were both related to emissions. These groups were valid for the spatial, seasonal, and annual trend data. Other elements, like $\mathrm{Ca}, \mathrm{K}$, total $\mathrm{P}$, and sulfate, were influenced by natural and anthropogenic processes. The seasonal variation of ammonium deposition was caused primarily by ammonia emissions and ancillary by precipitation. Most heavy metals as well as sulfate, nitrate, and ammonium showed decreasing trends in concentrations and deposition fluxes. Only $\mathrm{Hg}$ did not show any trend. The decreasing depositions of sulfate and total nitrogen were correlated to emission reductions in Germany. The deposition of most heavy metals was influenced by emission reductions on European scale and meteorological factors such as wind speed and humidity. Hg did not show any correlation with the emission time series in Europe. Instead, it was correlated to the NAO index and wind, implying that global emissions and transport pathways determine the temporal development of $\mathrm{Hg}$ depositions. Overall, the study reveals that emission reductions positively influence regional depositions for most investigated substances. The regional spatial patterns of depositions were also influenced by local meteorological factors.

Keywords Atmospheric deposition - Trend analysis - Multivariate statistics - Time series decomposition $\cdot$ Heavy metals $\cdot$ Nutrients 


\section{Introduction}

The alteration of the atmospheric deposition, due to human emissions of particulate matter, heavy metals, nutrients, and other anthropogenic pollutants, is a global problem (Monks et al., 2009). The excessive deposition of sulfate, ammonium, and nitrate leads to an acidification and eutrophication of ecosystems, which can cause changes in biodiversity (Pascaud et al., 2016). In addition, the deposition and enrichment of heavy metals, like $\mathrm{Pb}, \mathrm{Cd}$, and $\mathrm{Hg}$, in ecosystems are a major environmental concern due to their persistence, ability to bio-accumulate, and their toxicological effects (Tørseth et al., 2012).

Anthropogenic sulfur and nitrogen emissions mainly originate from energy production $\left(\mathrm{SO}_{\mathrm{x}}\right.$ and $\left.\mathrm{NO}_{\mathrm{x}}\right)$, road transportation $\left(\mathrm{NO}_{\mathrm{x}}\right)$, and agriculture $\left(\mathrm{NH}_{3}\right.$ ) (Zhang et al., 2018). Some of the most important emission sources for heavy metals are the metal industry ( $\mathrm{Al}, \mathrm{As}, \mathrm{Cr}, \mathrm{Cu}, \mathrm{Fe}, \mathrm{Zn}$ ), other manufacturing industries and construction (As, $\mathrm{Cd}, \mathrm{Cr}, \mathrm{Hg}, \mathrm{Ni}$, $\mathrm{Pb})$, electricity and heat production $(\mathrm{Hg}, \mathrm{Ni})$, road transportation $(\mathrm{Cu}$ from brake wear, $\mathrm{Pb}$ from petrol, and $\mathrm{Zn}$ from tires), and phosphate fertilizers in agricultural areas (Cd) (Huang et al., 2009; Schröder et al., 2016).

$\mathrm{NO}_{\mathrm{x}}$ and $\mathrm{SO}_{2}$ emissions are decreasing in Europe and in the USA, but the rate of change is smaller in the USA, particularly for $\mathrm{NO}_{x}$ (Monks et al., 2009; Zhang et al., 2018). On a global scale, these emission reductions are compensated by increasing emissions in East Asia (Monks et al., 2009). In Europe, emissions of $\mathrm{SO}_{\mathrm{x}}, \mathrm{NO}_{\mathrm{x}}$, and most heavy metals have been reduced, since 1990, by national and international conventions and mitigation measures, like the UNEC Convention on Long-Range Transboundary Air Pollution (LRTAP) (UNECE, 1979).

Despite different analysis periods in the time 1990 to 2010, several authors found declining sulfur and nitrogen concentrations and deposition fluxes in Europe since 1990, in line with emission reduction policies (Aas et al., 2019; Tørseth et al., 2012; van der Swaluw et al., 2011; Vet et al., 2014; Waldner et al., 2014). Although on a national or regional scale, deviations from the general European trend occur (Hůnová et al., 2014; Pascaud et al., 2016; Winfried Schröder et al., 2014). For example, Pascaud et al. (2016) found decreasing trends in sulfate and hydrogen concentration at a large number of rural sites in France, but the trends in nitrogen compounds were not linked to emission inventory changes.

In addition, in the same period, long-term trends in heavy metal concentrations $(\mathrm{Pb}$ and $\mathrm{Cd})$ and deposition fluxes decreased since 1990 in Europe (Pacyna et al., 2009; Tørseth et al., 2012). Schröder et al. (2016) compared heavy metal long-term trends in mosses with EMEP (European Monitoring and Evaluation Programme) domain depositions and found decreasing trends for $\mathrm{Pb}, \mathrm{Cd}, \mathrm{Cr}, \mathrm{Zn}, \mathrm{Ni}, \mathrm{Fe}, \mathrm{As}, \mathrm{Hg}$, and $\mathrm{Cu}$ following emission reductions. Despite falling $\mathrm{Hg}$ emissions in Europe, no or only minor changes have been observed in $\mathrm{Hg}$ concentrations and deposition fluxes, depending on the investigated time periods (Torseth, 2012; Schröder et al., 2016; Pacyna et al., 2009). For all waters in Germany, $\mathrm{Hg}$ concentrations in river biota exceed the environmental quality standard defined by the EU water framework directive (BMUB/UBA, 2016). Direct $\mathrm{Hg}$ releases to surface waters have been greatly reduced over the last decades, and today, inputs are dominated by diffuse sources (e.g., atmospheric deposition, soil erosion, and the remobilization) (Wiederhold et al., 2020). The long live time of $\mathrm{Hg}$ in the atmosphere resulted in an increased focus on global $\mathrm{Hg}$ emission sources (HTAP, 2010; UNEP, 2013).

The magnitude of atmospheric deposition can be influenced by many factors such as the temporal development and spatial distribution of emission sources and meteorological factors (e.g., wind speed, temperature, or humidity) (Amodio et al., 2014; Mijić et al., 2010; Suvarapu \& Baek, 2017). Heavy metals, such as $\mathrm{Pb}, \mathrm{Cd}$, and $\mathrm{Hg}$, as well as sulfur and nitrogen aerosols, can be transported over long distances by atmospheric flow, before they are deposited far away from the emission sources (Pacyna et al., 1989). Therefore, it is sometimes equivocal, if observed trends in atmospheric deposition can be solely attributed to changes in emissions, because temporal changes in meteorological factor can further support or contradict changes.

The monitoring of precipitation chemistry often results in complex data sets that comprise a large number of physical-chemical parameters. However, simultaneous evaluation and interpretation of multiple parameters of such data sets was found to be difficult (Le et al., 2017). Consequently, there is a demand to apply approaches that provide deeper insights into complex environmental and anthropogenic dependencies. 
In this study, a comprehensive and complex data set of deposition measurements of 24 chemical parameters, including major ions, nitrogen, and phosphorous species as well as heavy metals, has been analyzed for a maritime region in northern Germany. To explore the relationships between the parameters and furthermore the relationships of the parameters to another data set of environmental variables, canonical ordination methods were applied (Borcard et al., 2011). Although multivariate constrained ordination methods, like redundancy analysis (RDA), and variation partitioning are growing in popularity in ecological analysis and modelling (Dalu et al., 2017; Rico et al., 2016), they were rarely applied in other disciplines.

The first objective of the study was to explore the spatial and seasonal variation as well as trends of nutrients and heavy metal concentrations in precipitation and their deposition loads. The second objective of the study was to gain deeper insight in the relationships between data sets of deposition measurements, emission inventories, and meteorological factors, which were addressed by advanced multivariate ordination methods. Therefore, time series decomposition algorithms were used together with multivariate analysis methods to gain insight in: (1) the spatial and seasonal variation, (2) the temporal patterns (longterm trends), as well as (3) the relative influence of the temporal development of emission inventories and meteorological factors on the temporal development of selected parameters.

\section{Methods}

Sampling sites and chemical analysis

The 12 sampling sites of this study are located in the federal state Schleswig-Holstein in northern Germany (Fig. 1). Schleswig-Holstein is the most northern part of Germany, enclosed by the North Sea in the West and the Baltic Sea in the East. Geographically, this region is part of the North German Lowlands and is characterized by an oceanic climate. The annual mean temperature is $8.3{ }^{\circ} \mathrm{C}$ and the wind direction is dominated by prevailing westerlies (Beyn et al., 2014).

All sampling sites were equipped with automatic precipitation collectors (OTT Pluvio 2), bulk samplers, and automatic wet-only samplers. Bi-weekly composite samples were collected from the wet-only samplers to analyze nutrients $\left(\mathrm{NH}_{4}{ }^{+}, \mathrm{NO}_{2}{ }^{-}, \mathrm{NO}_{3}{ }^{-}\right.$, total nitrogen $(\mathrm{N})$, and total phosphorous $(\mathrm{P}))$ as well as major ions $\left(\mathrm{Cl}^{-}, \mathrm{Na}^{+}, \mathrm{K}^{+}, \mathrm{Ca}^{2+}, \mathrm{Mg}^{2+}, \mathrm{SO}_{4}{ }^{2-}\right)$ and dissolved organic carbon (DOC). Four-week composite samples were collected from the bulk samplers to analyze heavy metals (Fe, Mn, As, Cd, Cr, Pb, Cu, Ni, Zn, and $\mathrm{Hg}$ ) and $\mathrm{Al}$. The samples were analyzed in the state laboratory Schleswig-Holstein (Table 1). The quality assurance of the chemical analyses was continuously realized by the annual participation at the laboratory ring tests at the Norwegian Institute for Air Research (NILU). Secondly, the laboratory had participated at ring tests of the European Monitoring and Evaluation Programme (EMEP) up to now for 38 times.

The time series of these sites were used for the seasonal and the trend analysis. At five sites, time series of 21 years (1997 to 2017) were available (Fig. 1). For the spatial analysis, the available data of all sites in the time period of 2012 to 2017 were used.

\section{Data processing}

Prior to data aggregation, three criteria were used to identify inappropriate data for analysis: (1) samples contaminated with dust or bird droppings, (2) data higher than mean plus three times the standard deviation, and (3) precipitation volume $<1 \mathrm{~mm}$ (Huang et al., 2008). Approximately $2 \%$ of the data were excluded from analyses according to the above criteria.

The time series were aggregated to monthly time series calculating volume-weighted mean concentrations $\left(C_{\mathrm{VW}}\right)$ according to Eq. 1:

$C_{\mathrm{VW}}=\frac{\sum_{i=1}^{n}\left(C_{\mathrm{i}} P_{\mathrm{i}}\right)}{\sum_{i=1}^{n} P_{\mathrm{i}}}$

where $n$ is the number of samples, $C_{\mathrm{i}}$ is the concentration, and $P_{\mathrm{i}}$ is the precipitation measured by the precipitation collector. The associated deposition fluxes (D) were calculated following Eq. 2:

$D=\sum_{i=1}^{n}\left(C_{\mathrm{i}} P_{\mathrm{i}}\right)$

The sea salt (ss) and non-sea salt ratios (nss) of the ions were estimated by Eqs. 3 and 4 (Honoki et al., 2007; Keene et al., 1986) based on sodium and the ionic concentration ratio of seawater expressed in eq/eq 
Fig. 1 Location and names of the sampling sites. The color and size of the symbols indicates the length of the available time series for each site

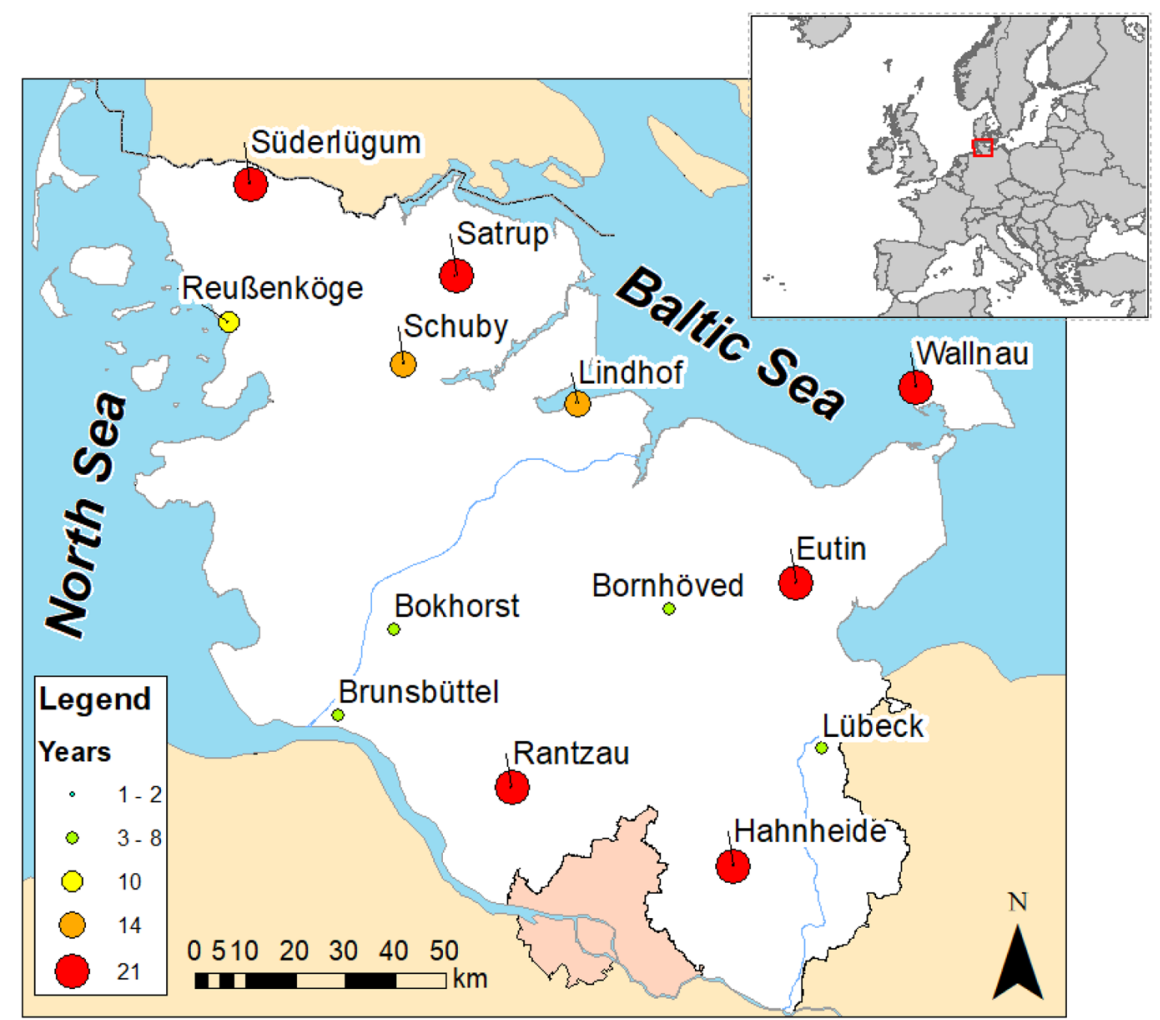

$s s I_{\mathrm{i}}=N a^{+}\left(I_{\mathrm{i}} / N a^{+}\right)_{\text {seawater }}$

where $I_{\mathrm{i}}$ is the concentration of one ion, e.g., $\mathrm{SO}_{4}{ }^{2-}$

$n s s I_{\mathrm{i}}=I_{\mathrm{i}}-N a^{+}\left(I_{\mathrm{i}} / N a^{+}\right)_{\text {seawater }}$

Additionally to the inter laboratory comparisons and quality checks carried out by the laboratory, checks on ion balance, comparison between measured and calculated conductivity, and $\mathrm{Na} / \mathrm{Cl}$ ratio were performed (Mosello et al., 2005) (Table 2).

Table 1 List of investigated substances and applied analytical methods

\begin{tabular}{ll}
\hline Parameter & Method \\
\hline $\mathrm{pH}$ & Potentiometric \\
$\mathrm{NH}_{4}^{+}, \mathrm{NO}_{2}^{-}, \mathrm{NO}_{3}{ }^{-}$, total $\mathrm{N}$, and & Continuous flow analyzer \\
total $\mathrm{P}$ & \\
$\mathrm{SO}_{4}^{2-}, \mathrm{Cl}^{-}$ & Flow injection analyzer \\
$\mathrm{Na}^{+}, \mathrm{K}^{+}, \mathrm{Ca}^{2+}, \mathrm{Mg}^{2+}, \mathrm{Al}, \mathrm{Fe}, \mathrm{Mn}$, & ICP-MS/MS, ICP-OES \\
$\mathrm{As}, \mathrm{Cd}, \mathrm{Cr}, \mathrm{Pb}, \mathrm{Cu}, \mathrm{Ni}, \mathrm{Zn}$ & \\
$\mathrm{Hg}$ & AFS \\
$\mathrm{DOC}$ & TOC analyzer \\
\hline
\end{tabular}

The check of the ion balance is based on the test of electronegativity of water samples. The ion balance is evaluated by the percentage difference (PD) of the sum of cations and sum of anions expressed in $\mu$ eq $1^{-1}$. The PD should be in the range $+/-10 \%$.

$P D=100 * \frac{\sum C a t-\sum A n}{0.5 *\left(\sum C a t+\sum A n\right)}$

The PD shows a range of 0.2 to 10.9 and the mean PD over all stations is 4.9 and is considered as acceptable.

The percentage difference (CD) between measured (CM) and calculated (CE) conductivity is given by:

$C D=100 * \frac{C E-C M}{C M}$ with $C E=\lambda_{\mathrm{i}} C_{\mathrm{i}}$

where $C E\left[\mu \mathrm{S} \mathrm{cm}^{-1}\right]$ is the sum of the concentrations [ $\mu$ eq $\mathrm{l}^{-1}$ ] and $\lambda\left[\mathrm{kS} \mathrm{cm} \mathrm{eq}^{-1}\right]$ is the equivalent conductance at infinite dilution of the ion i. Conversion factors are listed in Mosello et al. (2005). The $\mathrm{CD}$ should be in the range $+/-10 \%$. The $\mathrm{CD}$ shows a range of -13.4 to 10.9 and the mean $\mathrm{CD}$ over all stations is 1.9 and is considered as acceptable. 
Table 2 Summary of the percentage difference (PD) of the ion balance, $\mathrm{Na}+/ \mathrm{Cl}^{-}$ratio, and percentage difference (CD) of calculated (CE) vs. measured conductivity (CM). Units: ion concentrations $\mu \mathrm{eq} 1^{-1}$ and conductivity $\mu \mathrm{S} \mathrm{cm} \mathrm{cm}^{-1}$

\begin{tabular}{lllllllc}
\hline Site & Sum Cat & Sum An & PD & $\mathrm{Na}^{+} / \mathrm{Cl}^{-}$ & $\mathrm{CE}$ & $\mathrm{CM}$ & $\mathrm{CD}$ \\
\hline Bokhorst & 0.182 & 0.163 & 10.9 & 0.91 & 28.3 & 25.5 & 10.9 \\
Bornhöved & 0.158 & 0.141 & 10.9 & 0.90 & 25.0 & 25.4 & -1.6 \\
Brunsbüttel & 0.214 & 0.200 & 6.7 & 0.81 & 35.5 & 33.2 & 7.0 \\
Hahnheide & 0.124 & 0.119 & 3.9 & 0.85 & 23.6 & 25.5 & -7.3 \\
Hennstedt & 0.297 & 0.287 & 3.5 & 0.82 & 37.2 & 34.4 & 8.0 \\
Lindhof & 0.163 & 0.159 & 2.5 & 0.80 & 26.8 & 29.9 & -10.5 \\
Lübeck & 0.120 & 0.116 & 3.7 & 0.86 & 20.5 & 20.6 & -0.6 \\
Rantzau & 0.144 & 0.134 & 7.1 & 0.84 & 23.3 & 26.9 & -13.4 \\
Reußenköge & 0.260 & 0.247 & 5.3 & 0.83 & 40.5 & 38.4 & 5.6 \\
Satrup & 0.151 & 0.149 & 1.1 & 0.80 & 25.3 & 28.7 & -11.8 \\
Schuby & 0.205 & 0.195 & 5.1 & 0.85 & 32.3 & 34.5 & -6.4 \\
Süderlügum & 0.192 & 0.191 & 0.2 & 0.85 & 31.5 & 32 & -1.5 \\
Wallnau & 0.173 & 0.167 & 3.4 & 0.81 & 28.4 & 30.7 & -7.4 \\
Sites mean & & & 4.9 & 0.84 & 29.1 & & -1.9 \\
\hline
\end{tabular}

The ratio between $\mathrm{Na}^{+} / \mathrm{Cl}^{-}$should be expected not far from the marine value 0.89 in a range of 0.5 to 1.5 (Keene et al., 1986; Mosello et al., 2005). The CD should be in the range $+/-10 \%$. The ratio between $\mathrm{Na}^{+} / \mathrm{Cl}^{-}$shows a range of 0.8 to 0.91 with a mean ratio over all stations 0.84 and is considered as acceptable.

\section{Statistical methods}

Since strong seasonal variation can mask trends in parameters, the seasonal trend decomposition procedure based on non-parametric local regression (STL) was applied to extract a seasonal and trend component from the original time series (Cleveland et al., 1990). Based on the STL method, every data point in a time series is the sum of three independently interpretable components: (1) the seasonal component (high frequency), (2) the trend component (long-term change or low frequency), and (3) residual or random component. The STL method extracts the seasonal und trend component by an iterative local regression (LOESS) algorithm (Zobrist et al., 2018). A window width of 3 years for the seasonal and 6 years for the trend component was chosen for the smoothing parameters. A distinct longer smoothing period, such as 10 years, would mask meaningful information (Zobrist et al., 2018). The STL decomposition was performed for the five sites with 21 years of data (Fig. 1). The averaged time series over all sites is denoted as station mean. The extracted seasonal and trend component time series allow a separate evaluation, respectively. A data matrix for the spatial analysis was created by averaging concentrations and deposition fluxes in the time period from 2012 to 2017 for each of the 12 sites, respectively.

The seasonal Mann-Kendall test (MK) (Helsel et al., 2006) was applied to the trend components time series extracted by STL decomposition from the original time series. Marchetto et al. (2013) showed that the non-parametric seasonal Mann-Kendall trend test is most powerful to detect monotonic trends, although differences between trend methods become negligible for long time series. The Sen's method (Sen, 1968) was used to calculate the trend slope. Trends were considered significant if $p$-value $<0.05$.

PCA is a method to reduce the number of dimensions and complexity in a data matrix and therefore to identify groups, patterns, and relationships between the variables (Le et al., 2017). In PCA, a data set containing correlated variables will be transformed into a new data set containing new orthogonal, uncorrelated variables called principal components (PCs) (Olsen et al., 2012). PCA was applied to the spatial data matrix as well as the data matrices of the seasonal and trend components time series. Precipitation and wind velocity were included into the PCA, since they are dominant meteorological variables determining natural gradients in a maritime environment.

Redundancy analysis (RDA) was applied to evaluate the relative influence of time series of anthropogenic emissions and meteorological factors (explanatory variables) on the station mean concentration time series of the trend component (response variables). RDA is a method 
combining multiple linear regression and PCA, to extract the variance in a set of response variables that can be explained by a set of explanatory variables (Borcard et al., 2011; Legendre \& Legendre, 1998). Selected parameters were separated into three groups: (a) $\mathrm{SO}_{4}{ }^{2-}$ and total $\mathrm{N}$; (b) As, $\mathrm{Cd}, \mathrm{Cr}, \mathrm{Pb}, \mathrm{Cu}, \mathrm{Ni}$, and $\mathrm{Zn}$, and (c) $\mathrm{Hg}$. A RDA was performed for each group. Time series for the explaining meteorological factors (cloud cover, temperature, precipitation, wind velocity, sunshine duration, and humidity) stem from the weather station St. PeterOrding (DWD, 2018). Additionally, the North Atlantic Oscillation (NAO) index was included as further explanatory variable (CRU, 2019; Jones et al., 1997). The spatially averaged distribution of the wind velocities were received from DWD (2018). The emission time series for Germany and Europe were taken from EEA (2018). To reduce the number of regression variables, a PCA was applied to extract a single emission factor for Germany and Europe for the emissions of group (a) and group (b), respectively. To avoid inconsistencies, all the time series were aggregated to yearly means for the period 1997 to 2016. A forward selection algorithm was used to extract those explanatory variables that have highest explanatory power and show lowest collinearity (Blanchet et al., 2008; Borcard et al., 2011). The data sets were log transformed, centered, and $z$-scaled before passed to PCA and RDA. Monthly averaged ammonia emission data were extracted from Backes et al. (2016). The relative contribution of the two sets of explanatory variables (emissions and meteorological factors) to the total variance explained by the set of response variables was evaluated by variation partitioning (Borcard et al., 1992; Peres-Neto et al., 2006).

Multiple linear regression was applied to estimate seasonal variation of ammonia concentrations in precipitation. The formula of the multiple linear regression model is

$y=\beta_{0}+\beta_{1} X_{1}+\cdots+\beta_{\mathrm{n}} X_{\mathrm{n}}+\varepsilon$

where $y$ is the predicted value of the dependent variable, $\beta_{0}$ is the $y$ intercept, $\beta_{1}$ to $\mathrm{n}$ are the regression coefficients of the independent variables $X_{1}$ to n, and $\varepsilon$ is the model error (Legendre \& Legendre, 1998).

Statistical computations were implemented with the statistical open source software R (R Core Team, 2013) packages STPLplus (Hafen, 2016) and vegan (Oksanen et al., 2019).

\section{Results and discussion}

Dimension reduction - groups, patterns, and relationships between the parameters

Two main groups could be extracted from the parameters, based on ordination (PCA) (Fig. 2): (I) the marine group is formed by the elements $\mathrm{Cl}^{-}, \mathrm{Na}^{+}$, and $\mathrm{Mg}^{2+}$ and is related to natural processes. (II) The anthropogenic group is formed by the heavy metals $\mathrm{Pb}, \mathrm{Cd}, \mathrm{As}$, and $\mathrm{Zn}$ and is related to altered patterns and processes due to anthropogenic emissions. As a subgroup, the terrestrial group is formed by the elements $\mathrm{Fe}, \mathrm{Al}$, and $\mathrm{Mn}$, often referred as crustal elements. The assignment of $\mathrm{Cu}, \mathrm{Ni}$, and $\mathrm{Cr}$ to the anthropogenic or terrestrial group is less obvious. For the spatial PCA, they are related to the terrestrial group, but for the season and trend components, they are related to the anthropogenic group. The spatial, seasonal, or trend patterns of $\mathrm{Hg}$ are not related to any of the identified groups. The marine group is positively related to the wind velocity, which indicates the influence of sea spray. The anthropogenic group is inversely related to the precipitation. These three groups were valid for the spatial, seasonal, and trend data set, which underpins the role of fundamental processes for temporal patterns in depositions.

The anthropogenic group might be associated with anthropogenic emissions from traffic (mainly $\mathrm{Pb}$ : petrol and $\mathrm{Zn}$ : tires) and combustion for energy production and industrial processes (Huang et al., 2009; Schröder et al., 2016). As terrestrial, crustal elements, $\mathrm{Fe}, \mathrm{Al}$, and $\mathrm{Mn}$, are often related to resuspension of soil-derived particles (Huang et al., 2009), but they can also originate from traffic as well as steel and production industry (Mijić et al., 2010). $\mathrm{Cr}$ and $\mathrm{Ni}$ are mainly related to combustion and industrial production and they are important constituents of many metal alloys (Huang et al., 2009; Mijić et al., 2010). Potential sources for $\mathrm{Cu}$ are traffic related, especially brake abrasion (Rajsic et al., 2008). But these elements can also be enriched in soils due to fertilizer application (Atafar et al., 2009; Mortvedt, 1995). This suggests that the elements of the terrestrial group are influenced primarily by anthropogenic emission sources, like traffic and combustion, and secondarily by resuspension of soil particles. 


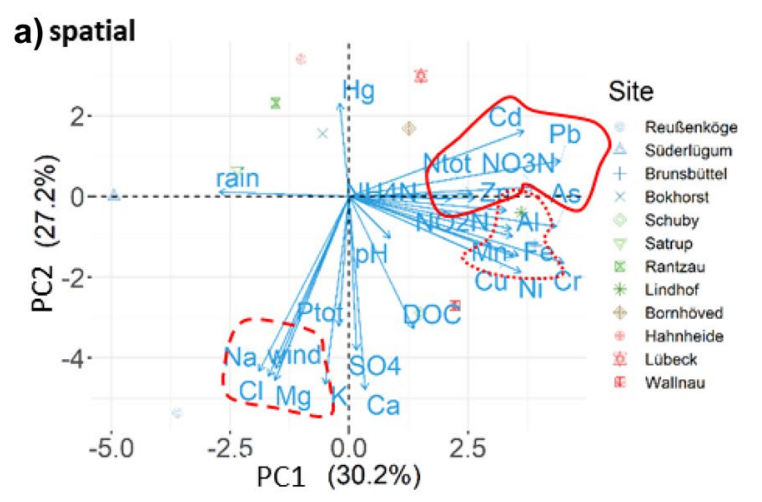

\section{b) seasonal}

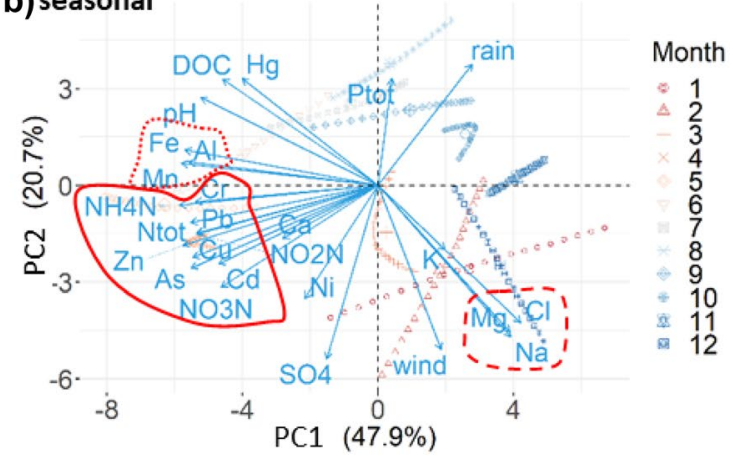

c) trend

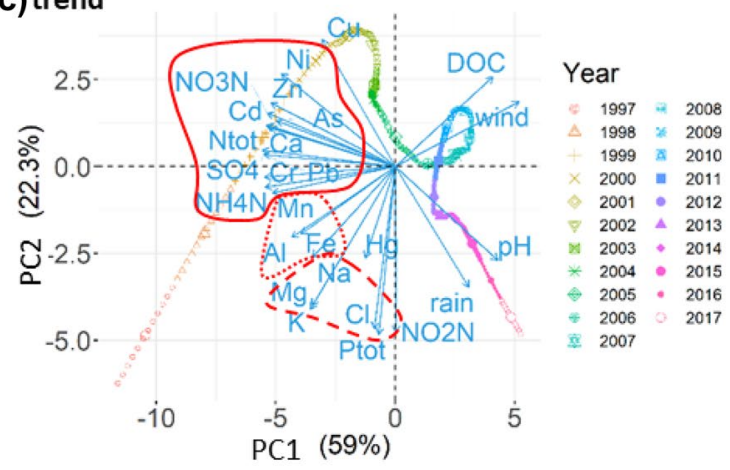

Groups:

marine :_; anthropogenic $\bigcirc$ terrestrial

Fig. 2 Principal component analysis of the a spatial data matrix as well as the time series of the $\mathbf{b}$ seasonal component and $\mathbf{c}$ trend component extracted from the original time series (1997 to 2017) by the STL method. Strongly related parameters are encircled and the identified groups are valid for the spatial, seasonal, and trend data matrix

Spatial distribution

\section{Marine group}

The investigated region shows strong spatial gradients in precipitation and wind velocity (Fig. 3a). This can be attributed to the marine environment with prevailing westerlies (Ganea et al., 2019). The spatial patterns of the marine group are strongly related to the spatial wind velocity gradient (Fig. 3a), corresponding to the diminishing influence of sea spray with increasing distance to the coast line, especially of the North Sea (Neumann et al., 2016). Hence, the elements of the marine group show a strong spatial gradient with higher concentrations and deposition fluxes in the northwest and lower in the southeast (Fig. 4).

\section{Anthropogenic and terrestrial group}

The annual mean concentrations and deposition fluxes of the investigated metals averaged over all sites are listed in Table 3. The spatial patterns of the elements of the anthropogenic group (Fig. 4) are inversely related to the precipitation, which is highest in the west and lowest in the east (Figs. 2 and 3a). Therefore, lower metal concentrations and deposition fluxes were found at the northern sites, where the precipitation is high. While concentrations tend to be elevated for most of the heavy metals at the Baltic site Wallnau ( $\mathrm{Pb}, \mathrm{Cr}, \mathrm{Cd}, \mathrm{Cu}, \mathrm{Zn}, \mathrm{As})$, deposition fluxes are not, reflecting the influence of the decreasing precipitation. The spatial patterns, related to these natural gradients, are altered by local emission sources. Most of the elements of the anthropogenic and terrestrial group show elevated concentrations and deposition fluxes around the site Lindhof in the east. On the one hand, this site is located in a high intensive agricultural area on sandy to loamy soils that are vulnerable to wind erosion (Duttmann et al., 2011). On the other hand, this site is located in the vicinity of the cities Kiel and Rendsburg as well as related traffic hot spots. Furthermore, the elements of the anthropogenic group show elevated depositions near the industrial site Brunsbüttel, where several refineries are located. Another potential emission source may be shipping emissions, due to combustion of shipping fuel (Viana et al., 2014). Highly frequented shipping routes are located close to the sites Lindhof, Brunsbüttel, and Wallnau (Neumann et al., 2018). Most of the heavy metals show only low to moderate spatial differences in the concentrations and deposition fluxes with a factor of approximately 1.5 to 2 . Only the elements of the terrestrial group show stronger differences with a factor of 3 . Therefore, under consideration of the dominating westerlies, background concentrations may be determined by long range distance transport of other industrial hot spots in Germany and Europe (UBA, 2018). 


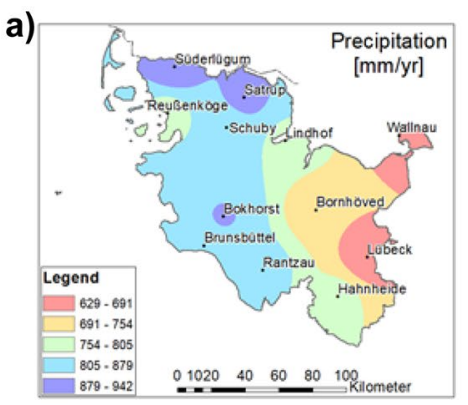

b)

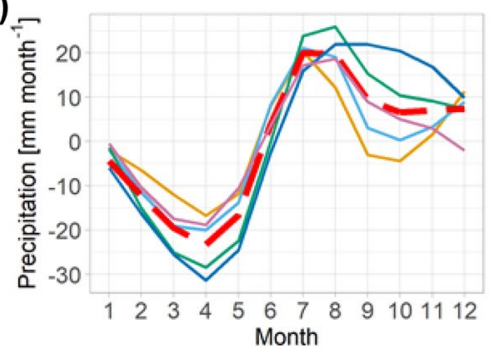

- Hahnheide

- Rantzau

- Satrup
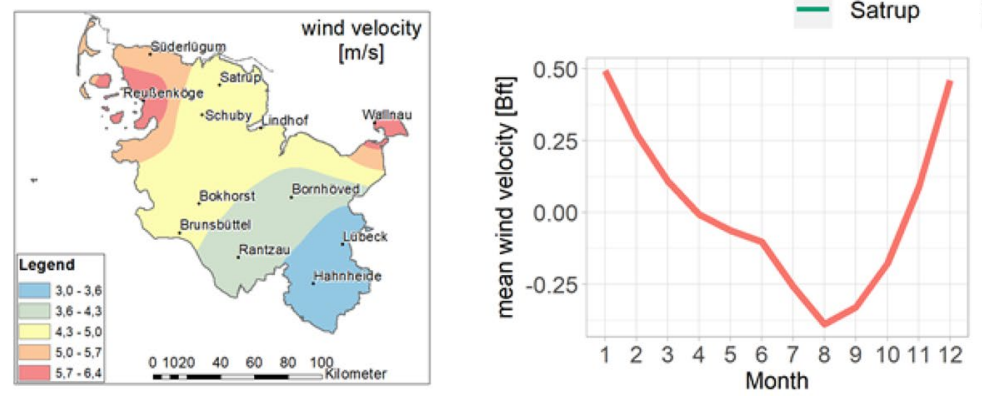

c)
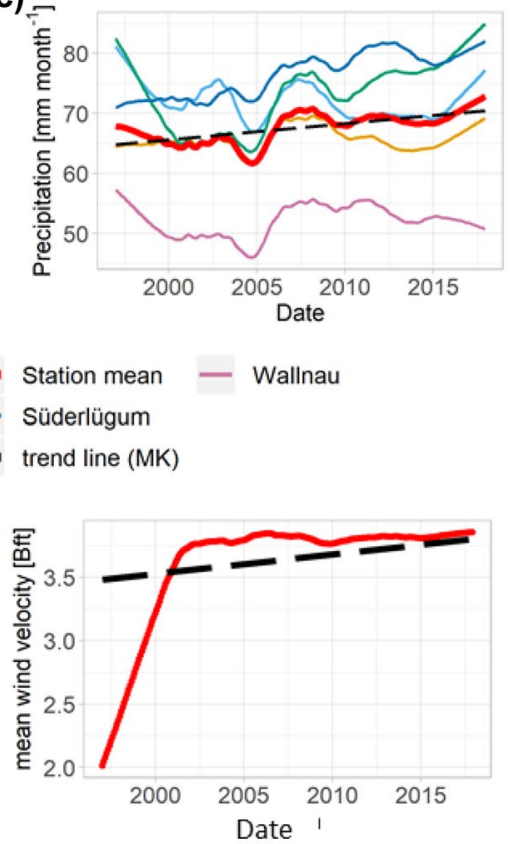

Fig. 3 a Interpolated (inverse distance weighted; IDW) annual mean precipitation and wind velocity in the period 2012 to 2017. b Seasonal component and c trend component extracted from the precipitation and wind velocity time series (2012 to 2017) by the STL method

\section{Sulfur, nitrogen, and phosphorus}

The annual mean concentration of total $\mathrm{N}$ is $1.3 \mathrm{mg} \mathrm{N}$ $\mathrm{L}^{-1}$ and the deposition flux is $10.4 \mathrm{~kg} \mathrm{~N} \mathrm{ha}^{-1}$ year $^{-1}$ in the period 2012 to $2017 . \mathrm{NH}_{4}{ }^{+}$is the dominant nitrogen species with $63 \%$, followed by $\mathrm{NO}_{3}{ }^{-}$with $36 \%$ and $\mathrm{NO}_{2}^{-}$with $1 \%$. The nitrogen species are associated with the anthropogenic group, reflecting the impact of anthropogenic emissions on their concentrations and deposition fluxes (Fig. 2). The relatively evenly spatial distribution of nitrogen deposition can mainly be attributed to high background ammonia emissions from livestock farming, since agriculture is the dominant land use in the region of Schleswig-Holstein with approx. 70\% (Jacobsen et al., 2019). Furthermore, EEA (2018) estimated that approx. $90 \%$ of the total $\mathrm{NH}_{3}$ emissions of Germany could be attributed to agricultural emissions. Nevertheless, similarly to the anthropogenic group, highest $\mathrm{NH}_{4}{ }^{+}$and hence total $\mathrm{N}$ concentrations and deposition fluxes were found at the industrial site Brunsbüttel, highlighting the potential importance of local industrial emission sources also for nitrogen (Fig. 4).
In addition, the shipping sector may contribute to elevated atmospheric depositions at coastal sites, since shipping emissions contribute to the nitrogen deposition with $13 \%$ in the North Sea and $16 \%$ in the Baltic Sea (Neumann et al., 2018) and for Sulfur with 6\% and $8 \%$ (Jalkanen et al., 2016).

The spatial patterns of other elements, like $\mathrm{Ca}^{2+}$, $\mathrm{K}^{+}$, total $\mathrm{P}$, and $\mathrm{SO}_{4}{ }^{2-}$, are grouped somewhere between the marine and anthropogenic group, indicating that natural patterns are altered by anthropogenic emissions (Fig. 2a). In addition, the high fraction of the non-sea salt concentration of these elements also indicates an alteration of the natural patterns by anthropogenic emissions $\left(77 \% \mathrm{nssCa}^{2+}\right.$, $74 \% \mathrm{nssK}^{+}$, and $73 \% \mathrm{SO}_{4}{ }^{2-}$ ). The general spatial patterns of $\mathrm{SO}_{4}{ }^{2-}$ and $\mathrm{Ca}^{2+}$ are similar to the marine group, but they also show elevated concentrations and deposition fluxes at the industrial site Brunsbüttel (Fig. 4). Instead, $\mathrm{K}^{+}$and also total $\mathrm{P}$ that are part of many fertilizers show elevated concentrations and deposition fluxes in the northeast and east probably due to intense agriculture in the surroundings. Additionally, the PCA shows that the spatial 

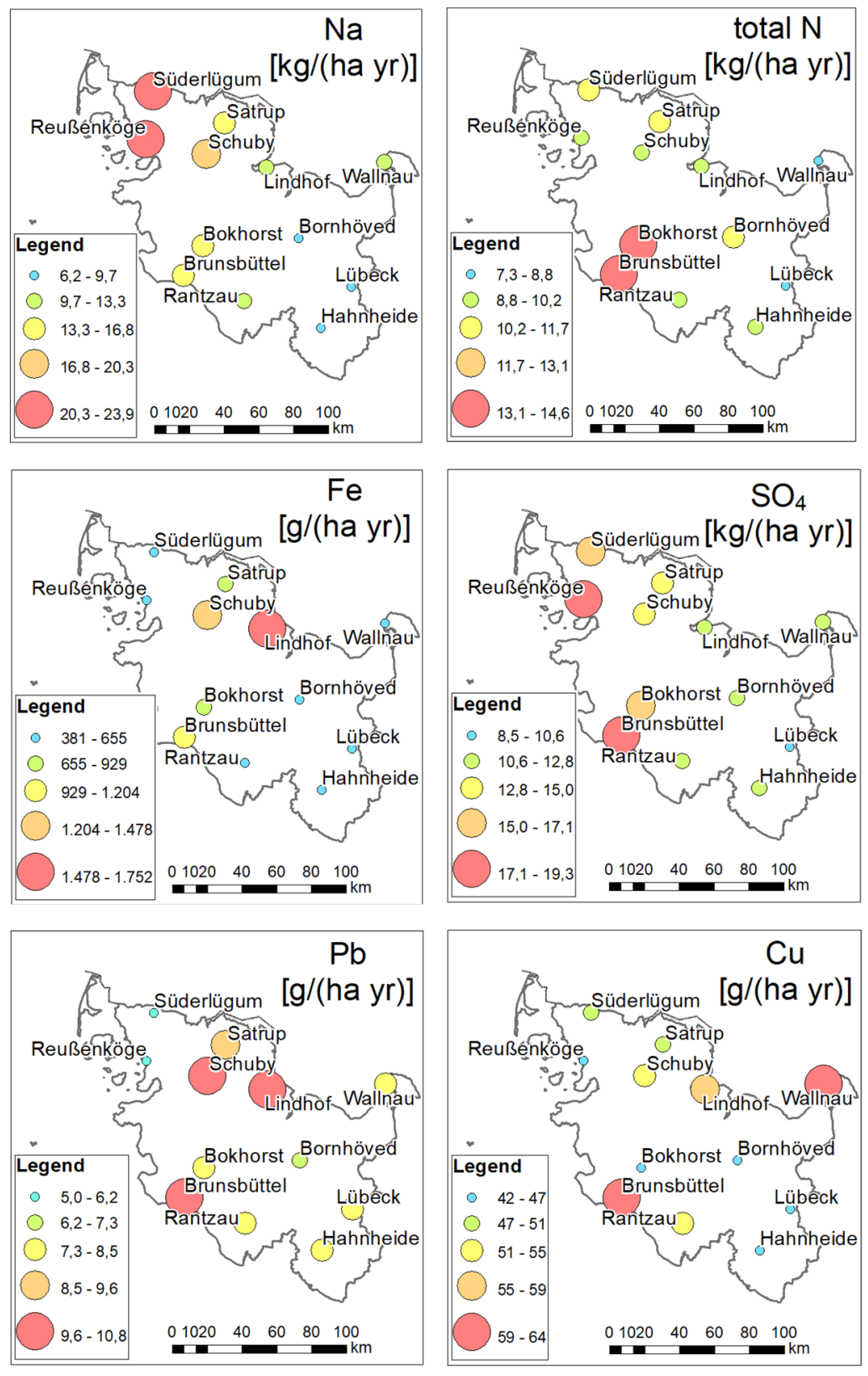
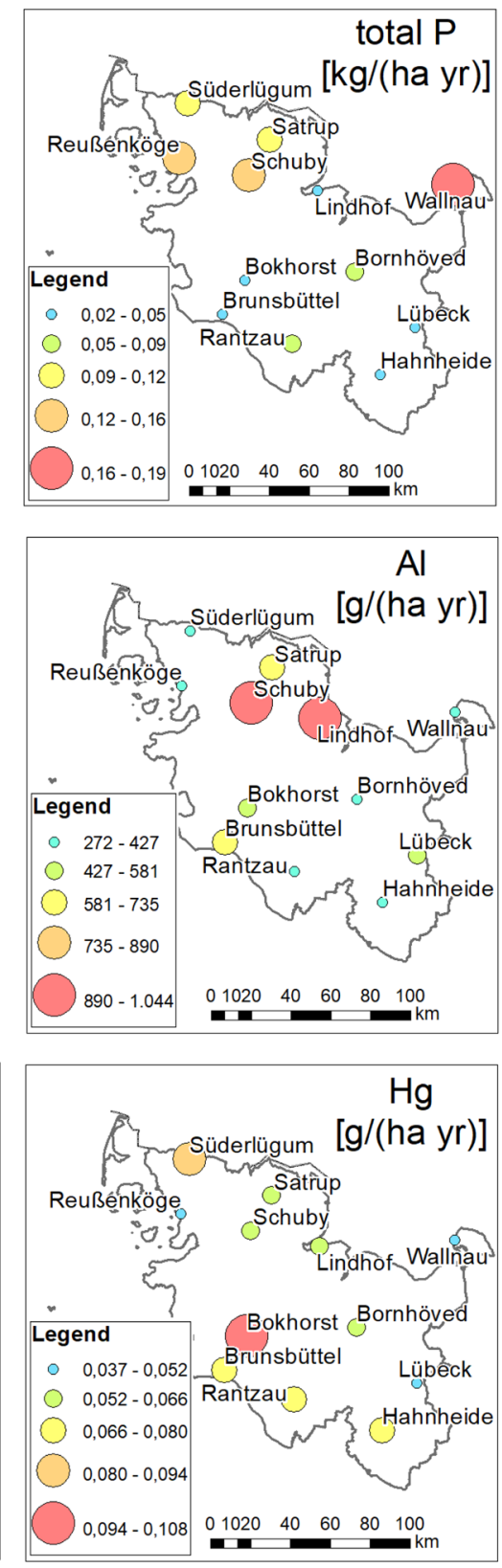

Fig. 4 Annual mean deposition fluxes of selected parameters in Schleswig-Holstein, Germany, for the period 2012-2017. The selected parameters are representative for the groups identified by PCA (Fig. 2a)

patterns of total $\mathrm{P}$ are moderately related to the marine group and wind. The average total $\mathrm{P}$ deposition flux normalized by precipitation over all sites with a non-agricultural surrounding $(n=5$; forest, industry, and city) is $0.06 \mathrm{~kg} \mathrm{P} \mathrm{ha}^{-1}$ year $^{-1}$. In comparison, the average total $\mathrm{P}$ deposition flux over all sites with an agricultural surrounding is $0.014 \mathrm{~kg}$
$\mathrm{P} \mathrm{ha}^{-1}$ year $^{-1}(n=7)$. Therefore, it can be assumed that the spatial variation in the phosphorus deposition is effected by local conditions, like agricultural management and local wind patterns. On the other hand, it has been shown that phosphorus is enriched in sea spray aerosols (Graham et al., 1979) and that sea spray aerosols can be an important phosphorus 
Table 3 Averaged concentrations and deposition flux of heavy metals and Al in the precipitation in the period 1997 to 2017. The parameters are ordered based on moles

\begin{tabular}{|c|c|c|c|}
\hline \multirow[b]{2}{*}{ Parameter } & \multicolumn{2}{|c|}{ Concentration } & \multirow{2}{*}{$\begin{array}{l}\text { Dep. flux } \\
\mathrm{g} \mathrm{ha}^{-1} \mathrm{yr}^{-1}\end{array}$} \\
\hline & $\mu \mathrm{g} \mathrm{L}^{-1}$ & $\mu \mathrm{mol} \mathrm{L}-1$ & \\
\hline $\mathrm{Al}$ & 64.302 & 2.382 & 521.09 \\
\hline $\mathrm{Fe}$ & 93.700 & 1.673 & 781.72 \\
\hline $\mathrm{Mn}$ & 8.738 & 0.159 & 72.47 \\
\hline $\mathrm{Zn}$ & 10.324 & 0.158 & 80.34 \\
\hline $\mathrm{Cu}$ & 6.427 & 0.101 & 51.17 \\
\hline $\mathrm{Ni}$ & 0.514 & 0.009 & 4.15 \\
\hline $\mathrm{Pb}$ & 1.030 & 0.005 & 8.02 \\
\hline $\mathrm{Cr}$ & 0.250 & 0.005 & 2.00 \\
\hline As & 0.134 & $1.79110^{-3}$ & 1.08 \\
\hline $\mathrm{Cd}$ & 0.044 & $3.95710^{-4}$ & 0.36 \\
\hline $\mathrm{Hg}$ & 0.008 & $4.04310^{-5}$ & 0.07 \\
\hline
\end{tabular}

source for coastal areas (Myriokefalitakis et al., 2016; Vignati et al., 2010).

\section{pH and $\mathrm{H}^{+}$deposition flux}

In the period 2012 to 2017 , the annual mean $\mathrm{pH}$ in precipitation is 5.9 and the averaged deposition flux of $\mathrm{H}^{+}$ is $20.2 \mathrm{eq} \mathrm{ha}^{-1}$. The results of the spatial PCA reveal that the $\mathrm{pH}$ has high loadings on $\mathrm{PC}$-axis 3, together with $\mathrm{SO}_{4}{ }^{2-}, \mathrm{NH}_{4}{ }^{+}$, total $\mathrm{N}$, and $\mathrm{Ca}^{2+}$, explaining $18.8 \%$ of the total spatial variance. In general, the $\mathrm{pH}$ in precipitation is higher in the west and lower in the east (Fig. 4). In correspondence with the emission hot spot of $\mathrm{SO}_{4}{ }^{2-}$ and $\mathrm{NH}_{4}{ }^{+}$, highest $\mathrm{pH}$ was observed at the industrial site Brunsbüttel. The ratio of nitrate to nonsea salt sulfate in precipitation is a useful indicator of the relative contribution of sulfuric acid $\left(\mathrm{H}_{2} \mathrm{SO}_{4}\right)$ and nitric acid $\left(\mathrm{HNO}_{3}\right)$ to the acidity of rain water (Itahashi et al., 2018). The ratio of $\mathrm{nssSO}_{4}{ }^{2-} /\left(\mathrm{NO}_{3}{ }^{-}+\mathrm{nssSO}_{4}{ }^{2-}\right)$ is 0.45 and therefore relatively balanced, with a slight dominance of $\mathrm{NO}_{3}^{-}$as main contributor to acidity (Wang et al., 2012). Nevertheless, because of the homogenous spatial distribution of $\mathrm{NO}_{3}{ }^{-}$, there is no significant correlation with the spatial distribution of the $\mathrm{pH}$. The average ratio of $\mathrm{NH}_{4}^{+} / \mathrm{nssBC}$ over all stations is 3.8. Higher concentrations of $\mathrm{NH}_{4}^{+}$than nssBC suggest that $\mathrm{NH}_{4}{ }^{+}$is the main contributor to neutralize acidity in rainwater. At all sites, the ratio of $\mathrm{NH}_{4}{ }^{+} / \mathrm{nssSO}_{4}{ }^{2-}$ was between 1.8 and 2.8 , indicating that ammonia can neutralize all the $\mathrm{H}_{2} \mathrm{SO}_{4}$, forming $\left(\mathrm{NH}_{4}\right)_{2} \mathrm{SO}_{4}$ particles (Pascaud et al., 2016). The significant correlations of the spatial distribution of the annual mean $\mathrm{pH}$ with $\mathrm{SO}_{4}{ }^{2-}$ (Spearman correlation $r=0.62, p<0.05)$ and $\mathrm{NH}_{4}{ }^{+}$(Spearman correlation $r=0.72, p<0.05)$ emphasize the dominant influence of these parameters on the spatial variation of $\mathrm{pH}$ in precipitation.

\section{Seasonal variation}

\section{Marine group}

The investigated parameters show different seasonal patterns. The seasonal patterns of the elements of the marine group $\left(\mathrm{Na}^{+}, \mathrm{Mg}^{2+}\right.$, and $\left.\mathrm{Cl}^{-}\right)$correspond very well with the mean wind velocity (Fig. 3b). Highest concentrations were found in the winter month and lowest during summer (Fig. 5). During the winter month, high wind velocities prevail and storm frequency are high (Dangendorf et al., 2014), resulting in a stronger influence of sea spray.

\section{Anthropogenic group and nutrients}

The seasonal variation of the concentrations of the elements of the anthropogenic group shows a moderate negative relationship to the precipitation, together with the nitrogen species (Fig. 2b). Although different emission sources could be expected, the seasonal patterns are very similar for all heavy metals and over all sites, except for $\mathrm{Ni}$ and $\mathrm{Cd}$. Most of the heavy metals and the nitrogen species show a concentration maximum around April to May, corresponding very well with the precipitation minimum during this time (Fig. 5). While the concentration minima around October to November is shifted in comparison to the precipitation maximum in August, the deposition fluxes are shifted according to the seasonal variation in precipitation, with highest deposition fluxes around June to July and lowest around February to March. The spatial and seasonal behavior of $\mathrm{Hg}$ is not related to the other metals, but there is a weak to moderate relation to $\mathrm{pH}$ and DOC (Fig. 2a, b). The amplitude of the concentrations and deposition fluxes of the heavy metals and nitrogen species is in a narrow range of $+/-30$ to $48 \%$ of the average. This range is in accordance with amplitude of the seasonal variation of the precipitation of $+/-30 \%$ (Fig. 2b). 

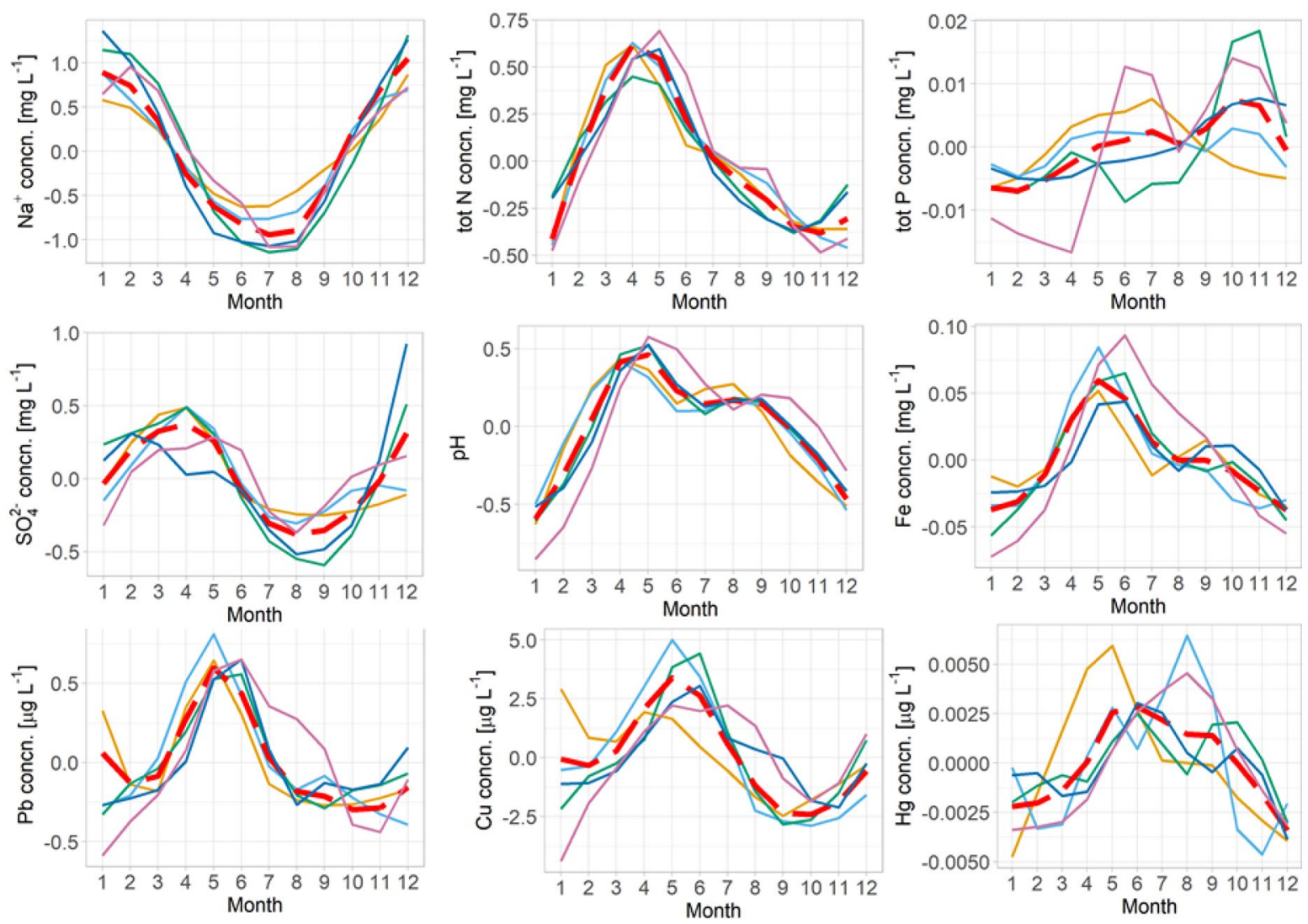

- Hahnheide - Satrup $\quad$ - Süderlügum
- Rantzau - Station mean - Wallnau

Fig. 5 Monthly concentration time series of the seasonal component extracted by STL regression method for selected parameters (1997 to 2017). The selected parameters are representative for the groups identified by PCA (Fig. 2b)

The results of the PCA indicate that the precipitation is one important factor to describe the seasonal patterns of the anthropogenic group. Beside meteorological factors, seasonal patterns of the emissions may play an important role. According to the forward selection, monthly averaged precipitation and $\mathrm{NH}_{3}$ emission time series were used as explanatory variables in a multiple regression model to estimate ammonia concentration in precipitation ( $p$-value $<0.001$, Fig. 6c). High ammonia concentrations in April and May are favored by low precipitation and high agricultural $\mathrm{NH}_{3}$ emissions during this time, due to slurry application (Wagner et al., 2017) (Fig. 6a, b), while high $\mathrm{NH}_{3}$ emissions in August are compensated by high precipitation, resulting in falling ammonia concentrations until the minima in November to December is reached. According to the results of the variation partitioning, the seasonal variation of the ammonia concentrations is dominated by the seasonal patterns of the emission (60\%), although the precipitation has a considerable part on the seasonality with $17 \%$ of the total variation explained.

The seasonal patterns of total $\mathrm{P}$ showed a relatively strong variation from site to site, emphasizing the potential importance of local effects like agricultural management and wind patterns on the total $\mathrm{P}$ concentrations and deposition fluxes.

\section{pH and $H^{+}$deposition flux}

The seasonal variation of the $\mathrm{pH}$ was also strongly correlated with the seasonal development of the $\mathrm{NH}_{4}{ }^{+} / \mathrm{nssSO}_{4}{ }^{2-}$ ratio (Pearson correlation $r=0.86$, $p<0.05)$. The $\mathrm{pH}$ in precipitation reached its maximum of 6.5 together with the $\mathrm{NH}_{4}{ }^{+} / \mathrm{nssSO}_{4}{ }^{2-}$ ratio 

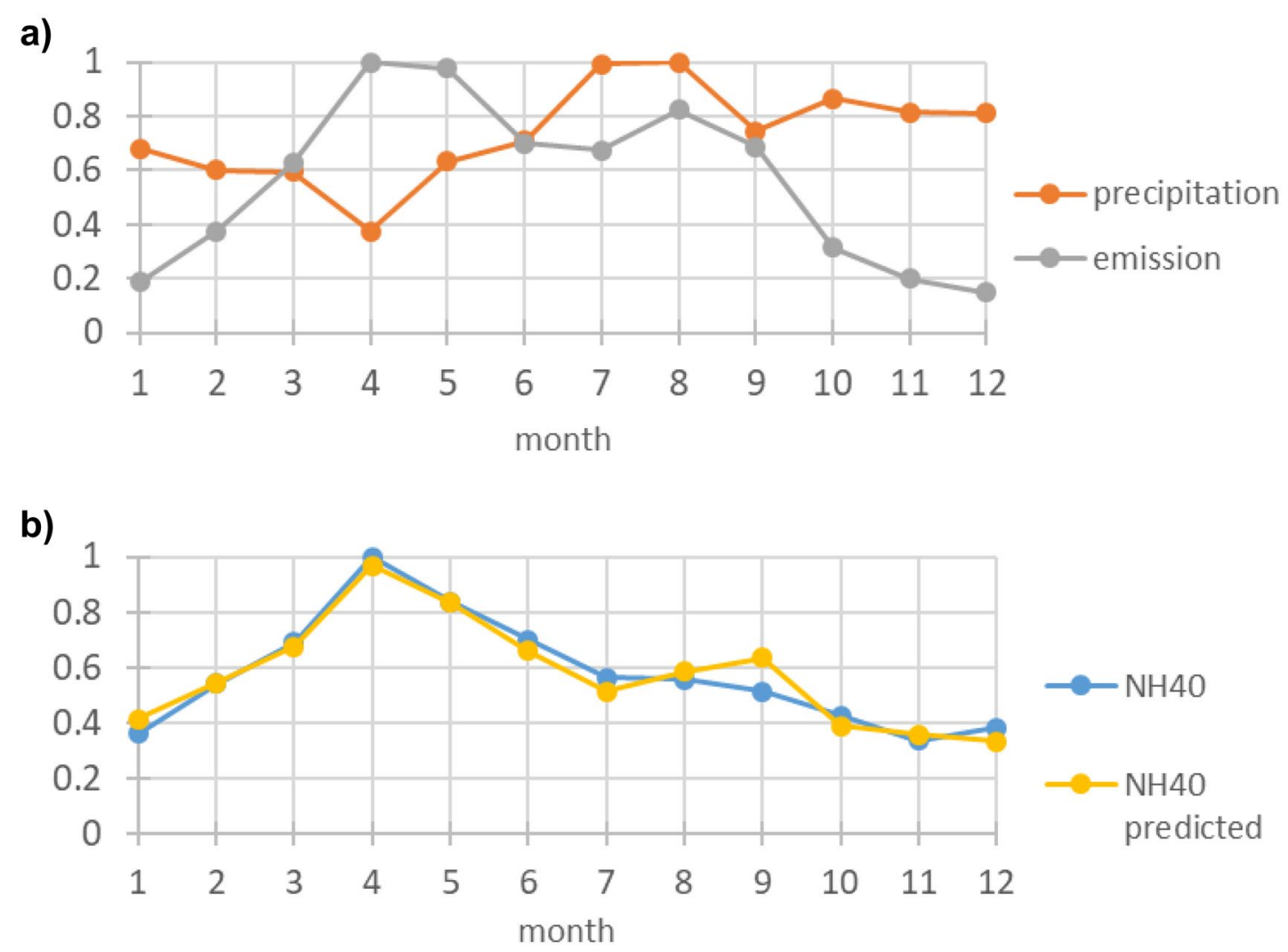

\section{c)}

\begin{tabular}{llll} 
Coefficients & Estimate & $\begin{array}{l}\text { Std. } \\
\text { Error }\end{array}$ & p-val \\
\hline Intercept & 0.636 & 0.088 & $<0.001$ \\
Precipitation & -0.468 & 0.099 & $<0.01$ \\
$\mathrm{NH}_{3}$ & 0.507 & 0.057 & $<0.001$ \\
emissions & & & \\
\hline $\begin{array}{l}\text { Adjusted R- } \\
\text { squared }\end{array}$ & 0.92 & & \\
\hline $\begin{array}{l}\text { Residual std. } \\
\text { error }\end{array}$ & 0.056 & & \\
& & &
\end{tabular}

Fig. 6 Results of the modelling of the seasonal component of the $\mathrm{NH}_{4}{ }^{+}-\mathrm{N}$ concentrations. a Standardized predictor variables: monthly averaged precipitation and $\mathrm{NH}_{4}{ }^{+}$-emission data. b Measured and predicted $\mathrm{NH}_{4}{ }^{+} \mathrm{N}$ concentrations of

of 2.7 in April to May. In spring, $\mathrm{NH}_{3}$ emissions were at their maximum and the available amount of $\mathrm{NH}_{4}{ }^{+}$to neutralize $\mathrm{SO}_{4}{ }^{2-}$ is twice as high as in winter, leading to highest $\mathrm{pH}$ values during the year. The minimum of the $\mathrm{NH}_{4}{ }^{+} / \mathrm{nssSO}_{4}{ }^{2-}$ ratio was reached

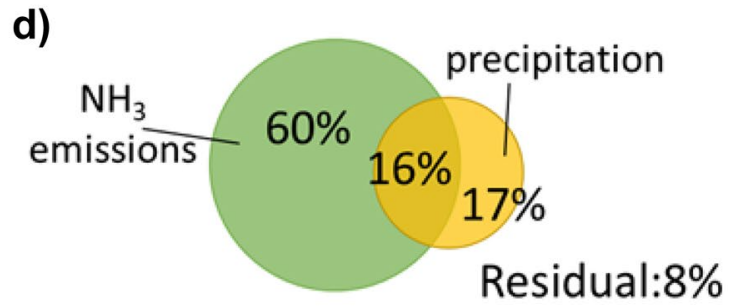

the seasonal component (standardized). c Summary table of the regression models results. d Venn diagrams displaying the results of the variation partitioning analysis. The size of the diagrams is scaled to the total variance explained

in December with 1.4. During winter, the $\mathrm{SO}_{2}$ emissions were elevated, because of the heating period, and agricultural ammonia emissions were at their minimum, leading to lowest $\mathrm{pH}$ values of 5.4 during the year. 
Trends in depositions from 1997 to 2017

For the 24 investigated parameters, 21 and 20 significant trends for concentration and deposition flux could be determined, respectively (Table 4). Of those, 4 and 17 substances exhibited increasing or decreasing significant trends for concentration, respectively. In the case of the deposition flux, 4 parameters show increasing and 16 decreasing trends.

\section{Marine group and precipitation}

The northern sites (Süderlügum and Satrup) show a significant and notable increase in precipitation, ranging from +16 to $+25 \% 21$ year $^{-1}$, whereas the southern and eastern sites show comparably small and contrary changes. The mean trend over all sites shows a significant

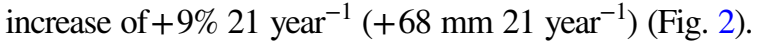
This is in accordance with Caloiero et al. (2018) who reported increases in precipitation for central and northern Europe (more than $20 \mathrm{~mm} / 10$ years) and seem to be connected to northern latitudes and exposure to the westerlies (BACC, 2008).

There is a notable increase of the wind velocities in the early part of the time series, followed by a period with comparably small changes. This pattern was also observed by Ganea et al. (2019), although they found slight decreasing trends for the longer time series of 35 years from 1983 to 2017. For the time period 1997 to 2017, the wind velocities show a significant increase of $+6.9 \% 21$ year $^{-1}$ (Fig. 2).

The marine elements $\left(\mathrm{Na}^{+}, \mathrm{Cl}^{-}, \mathrm{Mg}^{2+}\right)$ are grouped together by the PCA, also in the case of the trend component time series (Fig. 2c). Significantly decreasing trends of the concentrations and deposition fluxes were mostly observed at the sites closer to the Baltic Sea, while the site Süderlügum, which is located at the North Sea, shows increasing trends (Fig. 7). Although the precipitation trend is increasing at the sites Süderlügum and Satrup, they show contrary trends in the concentrations and deposition fluxes of the marine elements. This may be attributed to the diminishing influence of sea spray, whose influence dominates at areas within approximately $25 \mathrm{~km}$ from the coastline in the main wind direction (Chen et al., 2016).

\section{Anthropogenic group and nutrients}

The elements of the anthropogenic group show considerable decreasing trends in concentrations and deposition fluxes in the period of 1997 to 2017 (Fig. 7 and Table 4). $\mathrm{Pb}$ shows the strongest decreasing relative trend slope for the concentration with $80 \% 21^{-1}$ year $^{-1}$ and As the smallest with $30 \% 21^{-1}$ year $^{-1}$. The terrestrial group shows weak decreasing trends and, except for $\mathrm{Mn}$, no significant trends for the deposition flux. The relative trends of the heavy metals correspond with the reported European emission reductions (Fig. 8), implying that the heavy metals are strongly influenced by long range distance transport.

The trend component time series of total $\mathrm{N}, \mathrm{NH}_{4}{ }^{+}$, and $\mathrm{NO}_{3}{ }^{-}$and $\mathrm{SO}_{4}{ }^{2-}$ are closely grouped together with the anthropogenic group, indicating a strong influence of anthropogenic emissions on their temporal development (Beyn et al., 2014). Their concentrations and deposition fluxes are decreasing significantly at all sites and the magnitude of the decreasing relative trends corresponds well with the reported emission reductions for Germany (EEA, 2018). The decreasing trends of the nitrogen species of approximately $-30 \% 21^{-1}$ year $^{-1}$ for the concentrations and $-25 \% 21^{-1}$ year $^{-1}$ for the deposition flux correspond well with the reduction of the summed $\mathrm{NO}_{\mathrm{x}}+\mathrm{NH}_{3}$ emissions of $-35 \%$ for Germany in the last two decades. The reduction of the emissions can mainly be attributed to $\mathrm{NO}_{\mathrm{x}}$ reductions, while $\mathrm{NH}_{3}$ emissions were almost stable. Also, the decreasing trends of the concentrations and deposition flux of $\mathrm{SO}_{4}{ }^{2-}$ of $-49 \% 21^{-1}$ year $^{-1}$ and $-40 \% 21^{-1}$ year $^{-1}$ correspond well with the relative $\mathrm{SO}_{\mathrm{x}}$ emission reductions of Germany of $-53 \%$, implying that the trends of $\mathrm{SO}_{4}{ }^{2-}$ and the nitrogen species are more influenced by local and regional emission sources. Conversely, the trend component time series of $\mathrm{NO}_{2}{ }^{-}$is positively related to the precipitation and $\mathrm{pH}$. All sites show significantly increasing trends, with approximately $+56 \% 21$ year $^{-1}$ for the concentrations and $+108 \% 21$ year $^{-1}$ for the deposition flux.

As it is the case for the spatial PCA, the trend component time series of total $\mathrm{P}$ is strongly related to the marine group. Although the overall trends in concentrations and deposition flux of total $\mathrm{P}$ are not significant, increasing trends have been found for total $\mathrm{P}$ concentrations and deposition fluxes at the sites close to the sea, especially at the Baltic site Fehmarn. On the one hand, these increasing trends may be attributed to the intensive agricultural surrounding of these sites and increasing mean wind velocities, favoring wind erosion and sea spray input. On the other hand, 
Table 4 Trends estimated by seasonal Mann-Kendall test from the station mean trend component time series (1997 to 2017). The standard deviation is derived from the trends of the individual sites
Significant trend:

$* * p<0.05 ; * 0.05<p<0.1$

\begin{tabular}{|c|c|c|c|c|c|}
\hline \multirow[b]{2}{*}{ Parameter } & \multicolumn{2}{|l|}{ Concentration } & \multicolumn{3}{|l|}{ Deposition flux } \\
\hline & Slope & & Slope & & \\
\hline & & & {$\left[\mathrm{mm} 21 \mathrm{yr}^{-1}\right]$} & {$\left[\% 21 \mathrm{yr}^{-1}\right]$} & \\
\hline \multirow[t]{2}{*}{ Precipitation } & & & $68.1 \pm 87.6$ & $8.8 \pm 10.8 * *$ & \\
\hline & {$\left[21 \mathrm{yr}^{-1}\right]$} & {$\left[\% 21 \mathrm{yr}^{-1}\right]$} & & & \\
\hline \multirow[t]{2}{*}{$\mathrm{pH}$} & $0.719 \pm 0.234519$ & $13.7 \pm 4.7 * *$ & & & $* *$ \\
\hline & {$\left[\mathrm{mg} \mathrm{L}^{-1} 21 \mathrm{yr}^{-1}\right]$} & {$\left[\% 21 \mathrm{yr}^{-1}\right]$} & {$\left[\mathrm{kg} \mathrm{ha}^{-1} 21 \mathrm{yr}^{-1}\right]$} & {$\left[\% 21 \mathrm{yr}^{-1}\right]$} & \\
\hline $\mathrm{H}^{+}$ & $-0.009 \pm 0.003$ & $-80.2 \pm 12.5^{* *}$ & $-0.006 \pm 0.002$ & $-83.0 \pm 14.3^{* *}$ & \\
\hline $\mathrm{Cl}^{-}$ & $0.207 \pm 0.509$ & $7.4 \pm 14.5^{* *}$ & $0.252 \pm 0.513$ & $13.5 \pm 20.4^{* *}$ & \\
\hline $\mathrm{Na}^{+}$ & $-0.239 \pm 0.414$ & $-13.3 \pm 16.9^{* *}$ & $-0.104 \pm 0.296$ & $-8.7 \pm 20.3^{* *}$ & \\
\hline $\mathrm{K}^{+}$ & $0.020 \pm 0.091$ & $8.9 \pm 29.3^{*}$ & $0.036 \pm 0.038$ & $26.1 \pm 18.8^{* *}$ & \\
\hline $\mathrm{Ca}^{2+}$ & $-0.191 \pm 0.005$ & $-46.8 \pm 15.6^{* *}$ & $-0.129 \pm 0.081$ & $-48.5 \pm 15.3 * *$ & \\
\hline $\mathrm{Mg}^{2+}$ & $0.005 \pm 0.067$ & $-2.5 \pm 28.2$ & $0.001 \pm 0.038$ & $0.8 \pm 20.2^{*}$ & \\
\hline $\mathrm{SO}_{4}^{2-}$ & $-1.375 \pm 0.275$ & $-49.1 \pm 6.8^{* *}$ & $-0.702 \pm 0.200$ & $-40.9 \pm 5.3^{* *}$ & \\
\hline $\mathrm{NH}^{4+}-\mathrm{N}$ & $-0.296 \pm 0.075$ & $-29.6 \pm 6.2 * *$ & $-0.095 \pm 0.031$ & $-16.7 \pm 3.2 * *$ & \\
\hline $\mathrm{NO}_{2}^{-}-\mathrm{N}$ & $0.004 \pm 0.002$ & $57.3 \pm 33.5^{* *}$ & $0.004 \pm 0.001$ & $108.6 \pm 39.0 * *$ & \\
\hline $\mathrm{NO}_{3}{ }^{-}-\mathrm{N}$ & $-0.192 \pm 0.042$ & $-30.3 \pm 5.3 * *$ & $-0.101 \pm 0.026$ & $-26.1 \pm 2.1 * *$ & \\
\hline Ntot & $-0.513 \pm 0.072$ & $-31.0 \pm 4.0^{* *}$ & $-0.254 \pm 0.051$ & $-25.5 \pm 2.8 * *$ & \\
\hline Ptot & $0.002 \pm 0.012$ & $17.6 \pm 136$ & $0.003 \pm 0.008$ & $44.4 \pm 254$ & \\
\hline $\mathrm{Al}$ & $0.019 \pm 0.012$ & $-31.3 \pm 16.0^{*}$ & $-0.001 \pm 0.013$ & $-4.6 \pm 32.3$ & \\
\hline $\mathrm{Fe}$ & $-0.017 \pm 0.025$ & $-21.9 \pm 31.8^{*}$ & $0.003 \pm 0.021$ & $8.0 \pm 39.1$ & \\
\hline \multirow[t]{2}{*}{$\mathrm{Mn}$} & $-0.006 \pm 0.003$ & $-48.5 \pm 20.0^{*}$ & $-0.002 \pm 0.002$ & $-33.1 \pm 15.2 * *$ & \\
\hline & {$\left[\mu \mathrm{g} \mathrm{L}^{-1} 21 \mathrm{yr}^{-1}\right]$} & {$\left[\% 21 \mathrm{yr}^{-1}\right]$} & {$\left[\mathrm{g} \mathrm{ha}^{-1} 21 \mathrm{yr}^{-1}\right]$} & {$\left[\% 21 \mathrm{yr}^{-1}\right]$} & \\
\hline As & $-0.059 \pm 0.028$ & $-31.7 \pm 13.5^{* *}$ & $-0.024 \pm 0.010$ & $-22.1 \pm 7.2 * *$ & \\
\hline $\mathrm{Cd}$ & $-0.068 \pm 0.021$ & $-68.4 \pm 17.5^{* *}$ & $-0.033 \pm 0.015$ & $-58.4 \pm 17.8^{* *}$ & \\
\hline $\mathrm{Cr}$ & $-0.162 \pm 0.058$ & $-44.0 \pm 13.2^{* *}$ & $-0.063 \pm 0.025$ & $-30.4 \pm 11.2^{* *}$ & \\
\hline $\mathrm{Pb}$ & $-1.976 \pm 0.330$ & $-80.4 \pm 11.6^{* *}$ & $-0.949 \pm 0.228$ & $-69.2 \pm 10.3^{* *}$ & \\
\hline $\mathrm{Cu}$ & $-6.421 \pm 2.846$ & $-51.9 \pm 19.6^{* *}$ & $-3.028 \pm 1.517$ & $-42.7 \pm 13.8^{* *}$ & \\
\hline $\mathrm{Ni}$ & $-1.049 \pm 0.269$ & $-79.3 \pm 6.5^{* *}$ & $-0.672 \pm 0.105$ & $-80.4 \pm 3.3^{* *}$ & \\
\hline $\mathrm{Zn}$ & $-7.236 \pm 3.286$ & $-47.8 \pm 20.6^{* *}$ & $-3.225 \pm 2.336$ & $-37.5 \pm 20.0^{* *}$ & \\
\hline $\mathrm{Hg}$ & $-0.001 \pm 0.002$ & $-6.1 \pm 23.8$ & $0.000 \pm 0.001$ & $2.1 \pm 33.0$ & \\
\hline DOC & $0.098 \pm 0.151$ & $7.5 \pm 9.7 * *$ & $0.136 \pm 0.095$ & $17.0 \pm 11.2^{* *}$ & \\
\hline
\end{tabular}

increasing $\mathrm{P}$ contents in the water column of the Baltic Sea have been reported for the same period of time, which may lead to increased P concentrations in sea spray (Savchuk, 2018; Stigebrandt et al., 2013).

\section{pH and $H^{+}$deposition flux}

Significant increasing trends of $\mathrm{pH}$, ranging from +6 to $+20 \% 21$ year $^{-1}$, respectively, decreasing $\mathrm{H}^{+}$concentrations, ranging from -56 to $-91 \% 21$ year $^{-1}$, and decreasing deposition fluxes of $\mathrm{H}^{+}$, ranging from -56 to $-98 \% 21 \mathrm{year}^{-1}$, were recognized at all sites. These findings are in agreement with increasing $\mathrm{pH}$ trends in other neighboring European countries
(Pascaud et al., 2016; Tørseth et al., 2012; Vet et al., 2014). In the last two decades, the mean $\mathrm{pH}$ in precipitation increased by +0.7 units 21 year $^{-1}$. The $\mathrm{NH}_{4}{ }^{+} / \mathrm{nssSO}_{4}{ }^{2-}$ ratio increased from 1.4 to 2.3 , in the period 1997 to 2017, and is strongly correlated with the trend component time series of the $\mathrm{pH}$ (Pearson coefficient $=0.98, p<0.05$ ). Therefore, the increasing trends in $\mathrm{pH}$ can mainly be related to the decreasing trends of $\mathrm{SO}_{4}{ }^{2-}$ and $\mathrm{NH}_{4}{ }^{+}$and the resulting shift in the $\mathrm{NH}_{4}{ }^{+} / \mathrm{nsSSO}_{4}{ }^{2-}$ ratio, emphasizing the dominant influence on the temporal, seasonal, and spatial variation of the $\mathrm{pH}$. Therefore, emission reductions of $\mathrm{NH}_{4}{ }^{+}$and $\mathrm{SO}_{4}{ }^{2-}$ have to be balanced to avoid a shift to lower $\mathrm{pH}$. 

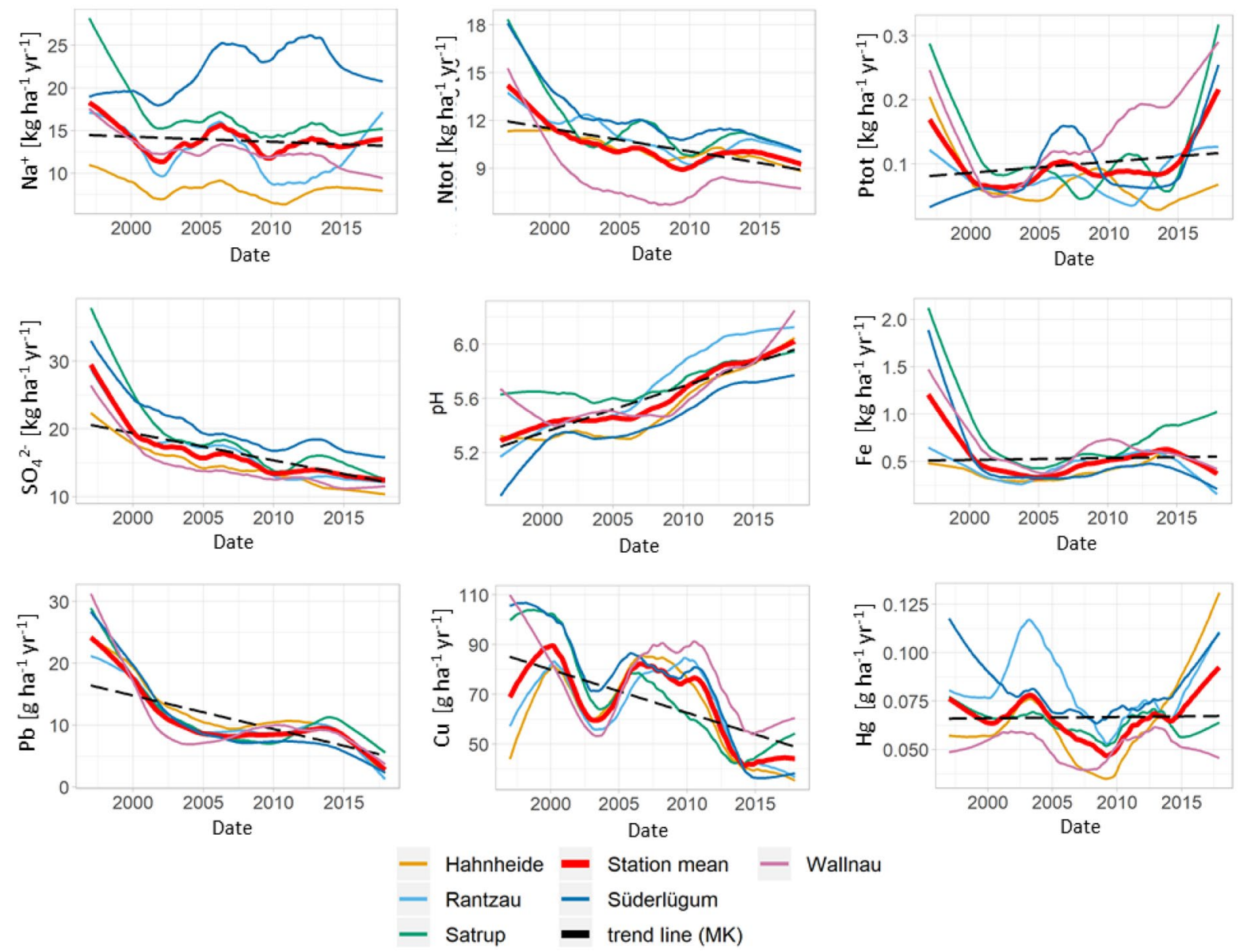

Fig. 7 Monthly time series of the deposition flux trend component extracted by STL regression method for selected parameters (1997 to 2017). The selected parameters are repre-

\section{Linking atmospheric deposition to meteorology and emissions}

RDA and variation partitioning were applied to evaluate the relative influence of the temporal development of emission inventories and meteorological factors (e.g., like wind velocity, precipitation, or humidity) on the time series of selected response variables. To reduce the number of regression variables, a PCA was applied to extract a single emission factor for Germany and Europe (see "Statistical methods" section). The extracted emission factors explain 94\% of the total variance of the emission data of group (a) and $92 \%$ of group (b), respectively. The results show that the influence of meteorological factors increases sentative for the groups identified by PCA (Fig. 2c). The black dotted line shows the Mann-Kendall trend line (MK)

with increasing distance to the dominant emission sources.

According to the forward selection, the emission factor of Germany and relative humidity were used as explanatory variables for the RDA model of the response variables $\mathrm{SO}_{4}{ }^{2-}$ and total $\mathrm{N}$ (see "Statistical methods" section). The emission factor and the response variables are strongly related to RDA Axis 1 , while humidity is related to Axis 2 . Axis 1 is most important and explains $97.8 \%$ of the variance of the response variables time series (Fig. 9a). The variation partitioning shows that $96 \%$ of the explained variance can be attributed to the emission factor of Germany (Fig. 10a). Therefore, the temporal development of the trend component time series of $\mathrm{SO}_{4}{ }^{2-}$ and total $\mathrm{N}$ 


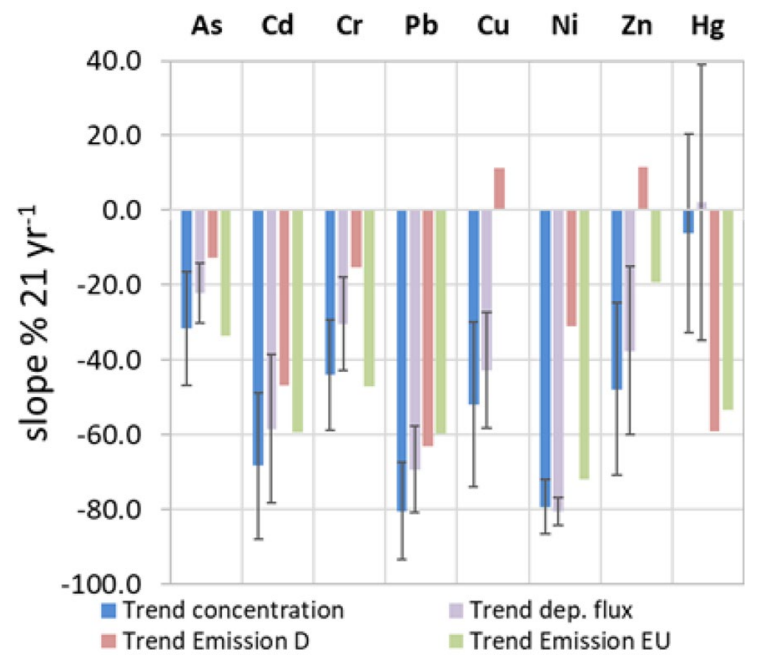

Fig. 8 Comparison of the relative slopes (seasonal MannKendall trend test) of the concentrations and deposition fluxes of the station mean trend component with the emission reductions reported for Germany (D) and the EU (EEA, 2018). Error bars indicate the standard deviation in respect to the individual sites

is clearly dominated by the temporal development of local and regional emission sources.

In the case of $\mathrm{As}, \mathrm{Cd}, \mathrm{Cr}, \mathrm{Pb}, \mathrm{Ni}, \mathrm{Cu}$, and $\mathrm{Zn}$, the emission factor of the EU, wind velocity, and relative humidity were detected as explanatory variables for the RDA. The RDA Axis 1 is most important, explaining $75.5 \%$ of the variance (Fig. 9b). The emission factor is strongly related to Axis 1 , while mean wind velocity is related to both axes. The temporal development of the response variables corresponds positively with the emission factor and negatively with the wind velocity. Thus, $\mathrm{Zn}, \mathrm{Pb}$, and Ni contribute most to the Axis 1 . Cu shows only a weak correlation with the emission factor and nearly no correlation with the meteorological factors. $\mathrm{Cu}$ has high loadings on the first unconstrained PC Axis 1 that explains $75 \%$ of the residual variance. Therefore, the temporal development of $\mathrm{Cu}$ cannot be explained by the available time series. Although there is a considerable amount of collinearity between the explanatory variables, the variation partitioning shows that $43 \%$ of the explained variance can be solely attributed to the emission factor, while $13 \%$ can be attributed to the meteorological factors mean wind velocity and relative humidity (Fig. 10b). Hence, the dominant factors for the temporal development of the concentration

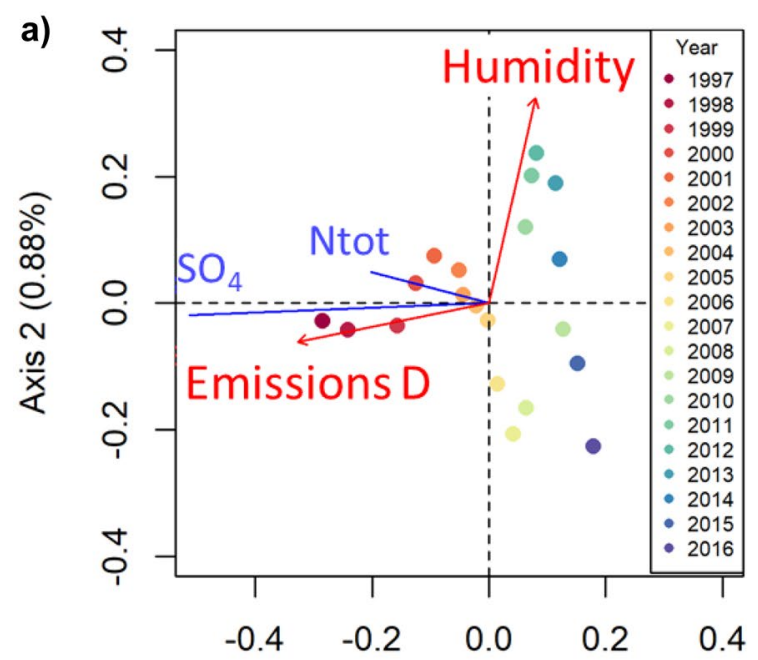

Axis $1(96.68 \%)$

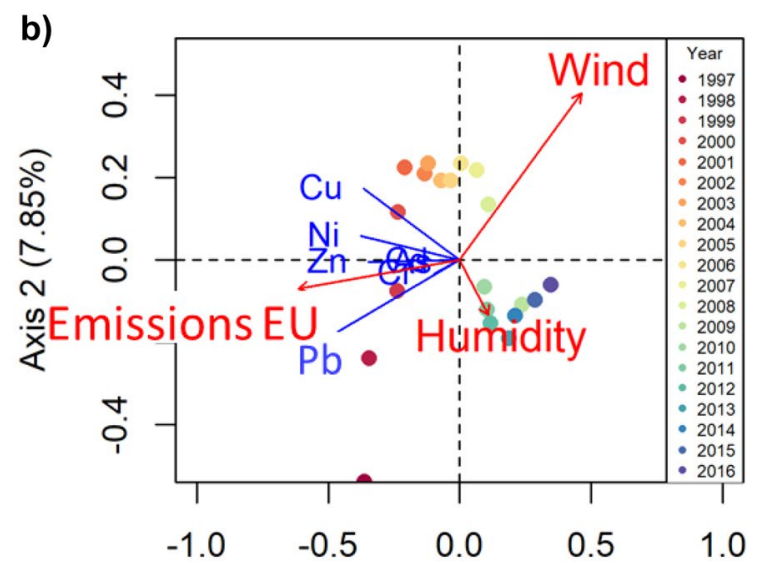

Axis $1(75.46 \%)$

Fig. 9 RDA triplot (scaling type 2) of the log transformed trend component time series of $\mathbf{a} \mathrm{SO}_{4}{ }^{2-}$ and total $\mathrm{N}$ and $\mathbf{b}$ As, $\mathrm{Cd}, \mathrm{Cr}, \mathrm{Pb}, \mathrm{Ni}, \mathrm{Cu}$, and $\mathrm{Zn}$ constrained by environmental variables (emission factor and meteorological factors). Blue lines are the response variables, red arrows are the environmental variables, and dots are the scores

time series of $\mathrm{As}, \mathrm{Cd}, \mathrm{Cr}, \mathrm{Pb}, \mathrm{Ni}$, and $\mathrm{Zn}$ are the emissions in Europe, but the meteorological factors wind and humidity have a considerable influence too, likely due to their impact on transport and dispersion (wind) and particle formation (humidity) (Amodio et al., 2014).

$\mathrm{Hg}$ does not show any correlation with the emission trends of Germany or the EU. Instead, the $\mathrm{Hg}$ 


\section{a) $\mathrm{SO}_{4}{ }^{2-}$ and total $\mathrm{N}$}

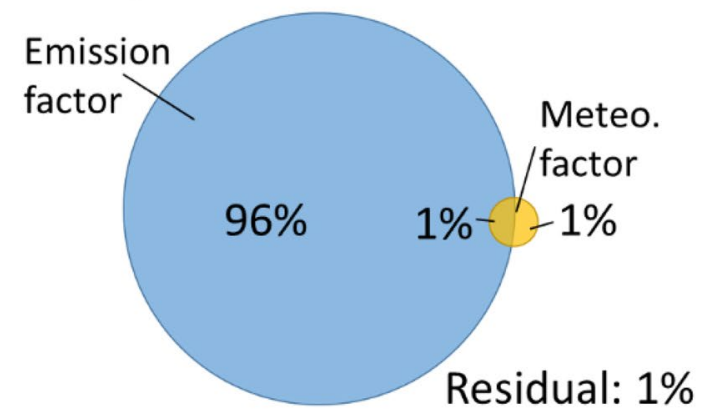

b) As, $\mathrm{Cd}, \mathrm{Cr}, \mathrm{Pb}, \mathrm{Ni}, \mathrm{Cu}$ and $\mathrm{Zn}$
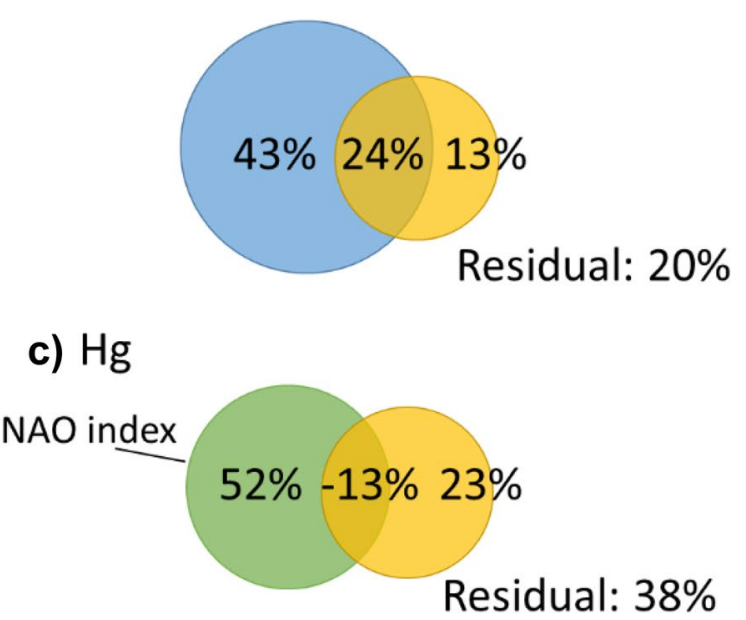

Fig. 10 Venn diagrams displaying the results of the variation partitioning analysis. The size of the diagrams is scaled to the total variance explained

trend component is correlated to the time series of the NAO index and wind velocity. Since only one response variable is considered, RDA is reduced to a multiple regression analysis. The resulting model explains $65.7 \%$ of the variance of the $\mathrm{Hg}$ time series. The temporal development of the $\mathrm{Hg}$ concentrations is positively related to the NAO index and negatively related to the mean wind velocity. The variation partitioning shows that $52 \%$ of the explained variance can be attributed to the temporal development of the NAO index and $23 \%$ to the mean wind velocity (Fig. 10c). The NAO index shows tendencies towards more positive NAO values, corresponding to stronger westerly winds (Hurrell et al., 2003). Hence, the positive correlation with the NAO index and the lack of significant correlations with the emission trends of
$\mathrm{Hg}$ in the Europe and Germany implies that global emissions and transport of $\mathrm{Hg}$ are an important factor for the temporal development of the trend component of the $\mathrm{Hg}$ concentrations. This result is in good agreement with modelling results of Christoudias et al. (2012), who found that the NAO phase is significantly correlated with North American gas and aerosol tracer concentrations over the northwestern Atlantic Ocean and across northern Europe.

\section{Conclusion}

Decreasing long-term trends in concentration and deposition flux could be identified for most of the identified parameters. Decreasing long-term trends of $\mathrm{NH}_{4}{ }^{+}$and $\mathrm{SO}_{4}{ }^{2-}$ are strongly correlated with emission reductions in Germany, estimated by EEA (2018). The reduction of nitrogen emissions is related to reductions of industrial and transportation emissions, highlighting the need for the reduction of agricultural nitrogen emissions. The ratio of $\mathrm{NH}_{4}{ }^{+} /$nonsea salt $\mathrm{SO}_{4}{ }^{2-}$ determines the spatial distribution as well as seasonal and long-term development of the $\mathrm{pH}$ in precipitation.

Decreasing long-term trends of $\mathrm{As}, \mathrm{Cd}, \mathrm{Cr}, \mathrm{Pb}$, $\mathrm{Ni}$, and $\mathrm{Zn}$ are dominated by emission reductions in Europe and meteorological factors. These findings support the importance of international conventions on emission reductions in order to achieve national environmental goals. Furthermore, it shows that meteorological factors can have a significant impact on the development of long-term trends. They can enhance or mitigate anthropogenic impacts on longterm trends.

The long-term trend of $\mathrm{Hg}$ shows no correlation to European and German emission inventories but to the North Atlantic oscillation (NAO). The annual NAO is a highly influential weather phenomenon as it controls the strength and direction of westerly winds in Europe. This correlation implies that both global emissions and transport of $\mathrm{Hg}$ are important factors for the temporal development of $\mathrm{Hg}$ depositions. For all waters in Germany, $\mathrm{Hg}$ concentrations in river biota exceed regulatory thresholds defined by the EU water framework directive. This highlights the importance for a global reduction of $\mathrm{Hg}$ emissions.

By the example of the seasonal variation of the ammonia concentrations, it has been shown that the 
knowledge of the seasonal variation of the emissions and driving meteorological factors is crucial to understand the seasonal variation of ammonia concentrations in precipitation.

The findings of this study are valuable for the evaluation of emission inventories and studies that are based on process-oriented emission and transport modelling. The time series decomposition into a seasonal and trend component enables to compare time series of selected measured parameters to available time series of emissions and meteorological factors. This technique aims to determine the decisive drivers and processes for regional depositions.

The identification of potential pollution hot spots and dominant drivers for the temporal development of seasonal variation and long-term trends of nutrients and heavy metals in atmospheric deposition helps local and regional decision-makers to develop and address expedient management strategies and measures. This approach will be extended in future studies to address the linkage of atmospheric deposition, emission factors, and meteorological factors to other environments, like concentration and loads in river basins.

Funding Open Access funding enabled and organized by Projekt DEAL. Ministerium für Energiewende, Landwirtschaft, Umwelt, Natur und Digitalisierung, des Landes SchleswigHolstein, Deutschland.

Availability of data and material Data can be provided on request.

\section{Declarations}

Conflict of interest The authors declare no competing interests.

Open Access This article is licensed under a Creative Commons Attribution 4.0 International License, which permits use, sharing, adaptation, distribution and reproduction in any medium or format, as long as you give appropriate credit to the original author(s) and the source, provide a link to the Creative Commons licence, and indicate if changes were made. The images or other third party material in this article are included in the article's Creative Commons licence, unless indicated otherwise in a credit line to the material. If material is not included in the article's Creative Commons licence and your intended use is not permitted by statutory regulation or exceeds the permitted use, you will need to obtain permission directly from the copyright holder. To view a copy of this licence, visit http://creativecommons.org/licenses/by/4.0/.

\section{References}

Aas, W., Mortier, A., Bowersox, V., Cherian, R., Faluvegi, G., Fagerli, H., Hand, J., Klimont, Z., Galy-Lacaux, C., Lehmann, C. M. B., Myhre, C. L., Myhre, G., Olivié, D., Sato, K., Quaas, J., Rao, P. S. P., Schulz, M., Shindell, D., Skeie, R. B., $\mathrm{Xu}, \mathrm{X}$. (2019). Global and regional trends of atmospheric sulfur. Scientific Reports, 9(1), 953.

Amodio, M., Catino, S., Dambruoso, P., \& De Gennaro, G., Gilio, A., Giungato, P., Laiola, E., Marzocca, A., Mazzone, A., Sardaro, A., Tutino, M. (2014). Atmospheric deposition: Sampling procedures, analytical methods, and main recent findings from the scientific literature. Advances in Meteorology, 2014, 1-27.

Atafar, Z., Mesdaghinia, A., Nouri, J., Homaee, M., Yunesian, M., Ahmadi, M., \& Mahvi, A. (2009). Effect of fertilizer application on soil heavy metal concentration. Environmental Monitoring and Assessment, 160, 83-89.

BACC. (2008). Assessment of climate change for the Baltic Sea basin: Springer-Verlag. Berlin Heidelberg.

Backes, A. M., Aulinger, A., Bieser, J., Matthias, V., \& Quante, M. (2016). Ammonia emissions in Europe, part II: How ammonia emission abatement strategies affect secondary aerosols. Atmospheric Environment, 126, 153-161.

Beyn, F., Matthias, V., \& Dähnke, K. (2014). Changes in atmospheric nitrate deposition in Germany-An isotopic perspective. Environmental Pollution, 194, 1-10.

Blanchet, F. G., Legendre, P., \& Borcard, D. (2008). Forward selection of explanatory variables. Ecology, 89(9), 2623-2632.

BMUB/UBA. (2016). Water Framework Directive: The status of German waters 2015. Bonn.

Borcard, D., Gillet, F., \& Legendre, P. (2011). Numerical ecology with R: Springer-Verlag.

Borcard, D., Legendre, P., \& Drapeau, P. (1992). Partialling out the spatial component of ecological variation. Ecology, 73(3), 1045-1055.

Caloiero, T., Caloiero, P., \& Frustaci, F. (2018). Long-term precipitation trend analysis in Europe and in the Mediterranean basin. Water and Environment Journal, 32(3), 433-445.

Chen, Y., Cheng, Y., Ma, N., Wolke, R., Nordmann, S., Schüttauf, S., Ran, L., Wehner, B., Birmili, W., van der Gon, H. A. C. D., Mu, Q., Barthel, S., Spindler, G., Stieger, B., Müller, K., Zheng, G. J., Pöschl, U., Su, H., \& Wiedensohler, A. (2016). Sea salt emission, transport and influence on size-segregated nitrate simulation: A case study in northwestern Europe by WRF-Chem. Atmospheric Chemistry and Physics, 16(18), 12081-12097.

Christoudias, T., Pozzer, A., \& Lelieveld, J. (2012). Influence of the North Atlantic Oscillation on air pollution transport. Atmospheric Chemistry and Physics, 12(2), 869-877.

Cleveland, R. B., Cleveland, W. S., McRae, J. E., \& Terpenning, I. (1990). STL: A seasonal-trend decomposition procedure based on Loess. Journal of Official Statistics, 6(1), 3-73.

CRU. (2019). Climatic Research Unit: NAO data files. Retrieved from https://crudata.uea.ac.uk/cru/data/nao/index.htm. last access June 2019.

Dalu, T., Wasserman, R. J., Tonkin, J. D., Mwedzi, T., Magoro, M. L., \& Weyl, O. L. F. (2017). Water or sediment? Partitioning the role of water column and sediment chemistry as drivers of macroinvertebrate communities in an austral South African stream. Science of The Total Environment, 607-608, 317-325. 
Dangendorf, S., Müller-Navarra, S., Jensen, J., Schenk, F., Wahl, T., \& Weisse, R. (2014). North Sea storminess from a novel storm surge record since AD 1843. Journal of Climate, 27(10), 3582-3595.

Duttmann, R., Hassenpflug, W., Bach, M., Lungershausen, U., \& Frank, J. -H. (2011). Winderosion in Schleswig-Holstein: Kenntnisse und Erfahrungen über Bodenverwehungen und Windschutz: LLUR SH - Geologie und Boden; 15. Flintbek.

DWD. (2018). DWD Climate Data Center (CDC): Historische monatliche Stationsbeobachtungen (Temperatur, Druck, Niederschlag, Sonnenscheindauer, etc.) für Deutschland, Version v007. Retrieved from https://opendata.dwd.de/ climate_environment/CDC/. last access May 2019.

EEA. (2018). National emissions reported to the convention on long-range transboundary air pollution (LRTAP Convention), Prod-ID: DAT-16-en Retrieved from https://www. eea.europa.eu/data-and-maps/data/national-emissionsreported-to-the-convention-on-long-range-transboundaryair-pollution-lrtap-convention-12\#tab-data-visualisations. last access June 2019.

Ganea, D., Mereuta, E., \& Rusu, E. (2019). An evaluation of the wind and wave dynamics along the European coasts. Journal of Marine Science and Engineering, 7(2), 43.

Graham, W. F., Piotrowicz, S. R., \& Duce, R. A. (1979). The sea as a source of atmospheric phosphorus. Marine Chemistry, $7(4), 325-342$.

Hafen, R. (2016). stlplus: Enhanced seasonal decomposition of time series by Loess. R package version 2.5-5. https:// CRAN.R-project.org/package $=$ stlplus

Helsel, D. R., Mueller, D. K., \& Slack, J. R. (2006). Computer program for the Kendall family of trend tests. U.S. Geological Survey Scientific Investigations Report 2005-5275.

Honoki, H., Watanabe, K., Iida, H., Kawada, K., \& Hayakawa, K. (2007). Deposition analysis of non sea-salt sulfate and nitrate along to the northwest winter monsoon in Hokuriku district by a snow boring core and bulk samples. Bulletin of Glaciological Research, 24, 23-28.

HTAP. (2010). Assessment of hemispheric transport of air pollution, Part B: Mercury. Air Pollution Studies No. 18. United Nations, NewYork and Geneva.

Huang, S., Tu, J., Liu, H., Hua, M., Liao, Q., Feng, J., \& Huang, G. (2009). Multivariate analysis of trace element concentrations in atmospheric deposition in the Yangtze River Delta East China. Atmospheric Environment, 43(36), 5781-5790.

Huang, Y., Wang, Y., \& Zhang, L. (2008). Long-term trend of chemical composition of wet atmospheric precipitation during 1986-2006 at Shenzhen City China. Atmospheric Environment, 42(16), 3740-3750.

Hůnová, I., Maznová, J., \& Kurfürst, P. (2014). Trends in atmospheric deposition fluxes of sulphur and nitrogen in Czech forests. Environmental Pollution, 184, 668-675.

Hurrell, J. W., Kushnir, Y., Ottersen, G., \& Visbeck, M. (2003). An overview of the North Atlantic oscillation. In J. W. Hurrell, Y. Kushnir, G. Ottersen, \& M. Visbeck (Eds.), The North Atlantic Oscillation: Climatic Significance and Environmental Impact (pp. 1-35): Geophysical Monograph.

Itahashi, S., Yumimoto, K., Uno, I., Hayami, H., Fujita, S. I., Pan, Y., \& Wang, Y. (2018). A 15-year record (2001-2015) of the ratio of nitrate to non-sea-salt sulfate in precipitation over East Asia. Atmospheric Chemistry and Physics, 18(4), 2835-2852.
Jacobsen, B. H., Latacz-Lohmann, U., Luesink, H., Michels, R., \& Ståhl, L. (2019). Costs of regulating ammonia emissions from livestock farms near Natura 2000 areas-Analyses of case farms from Germany, Netherlands and Denmark. Journal of Environmental Management, 246, 897-908.

Jalkanen, J. P., Johansson, L., \& Kukkonen, J. (2016). A comprehensive inventory of ship traffic exhaust emissions in the European sea areas in 2011. Atmospheric Chemistry and Physics, 16(1), 71-84.

Jones, P. D., Jonsson, T., \& Wheeler, D. (1997). Extension to the North Atlantic oscillation using early instrumental pressure observations from Gibraltar and south-west Iceland. International Journal of Climatology, 17(13), 1433-1450.

Keene, W. C., Pszenny, A. A. P., Galloway, J. N., \& Hawley, M. E. (1986). Sea-salt corrections and interpretation of constituent ratios in marine precipitation. Journal of Geophysical Research: Atmospheres, 91(D6), 6647-6658.

Le, T. T. H., Zeunert, S., Lorenz, M., \& Meon, G. (2017). Multivariate statistical assessment of a polluted river under nitrification inhibition in the tropics. Environmental Science and Pollution Research, 24, 1-18.

Legendre, P., \& Legendre, L. (1998). Numerical ecology-2nd. (English). Elsevier.

Marchetto, A., Rogora, M., \& Arisci, S. (2013). Trend analysis of atmospheric deposition data: A comparison of statistical approaches. Atmospheric Environment, 64, 95-102.

Mijić, Z., Stojić, A., Perišić, M., Rajšić, S., Tasić, M., Radenković, M., \& Joksić, J. (2010). Seasonal variability and source apportionment of metals in the atmospheric deposition in Belgrade. Atmospheric Environment, 44(30), 3630-3637.

Monks, P., Granier, C., Sandro, F., Stohl, A., Williams, M., Akimoto, H., \& von Glasow, R. (2009). Atmospheric composition change-global and regional air quality. Atmospheric Environment, 43, 5268-5350.

Mortvedt, J. J. (1995). Heavy metal contaminants in inorganic and organic fertilizers. Fertilizer research, 43(1), 55-61.

Mosello, R., Amoriello, M., Tiziana, A., Arisci, S., Carcano, A., Clarke, N., Derome, J., Derome, K., Koenig, N., Tartari, G., \& Ulrich, E. (2005). Validation of chemical analyses of atmospheric deposition in forested European sites. Journal of Limnology, 64, 93-102.

Myriokefalitakis, S., Nenes, A., Baker, A. R., Mihalopoulos, N., \& Kanakidou, M. (2016). Bioavailable atmospheric phosphorous supply to the global ocean: A 3-D global modeling study. Biogeosciences, 13(24), 6519-6543.

Neumann, D., Matthias, V., Bieser, J., Aulinger, A., \& Quante, M. (2016). A comparison of sea salt emission parameterizations in northwestern Europe using a chemistry transport model setup. Atmospheric Chemistry and Physics, 16, 9905-9933.

Neumann, D., Radtke, H., Karl, M., \& Neumann, T. (2018). Evaluation of atmospheric nitrogen inputs into marine ecosystems of the North Sea and Baltic Sea-part B: Contribution by shipping and agricultural emissions. Biogeosciences Discussion, 2018, 1-31.

Oksanen, J., Blanchet, F. G., Friendly, M., Kindt, R., Legendre, P., McGlinn, D., Minchin, P. R., O’Hara, R. B., Simpson, G. L., Solymos, P., Stevens, M. H. H., Szoecs, E., \& Wagner, H. (2019). vegan: Community ecology package. R package version 2.5-5. https://CRAN.R-project.org/package=vegan 
Olsen, R. L., Chappell, R. W., \& Loftis, J. C. (2012). Water quality sample collection, data treatment and results presentation for principal components analysis-literature review and Illinois River watershed case study. Water Research, 46(9), 3110-3122.

Pacyna, J. M., Bartonova, A., Cornille, P., \& Maenhaut, W. (1989). Modelling of long-range transport of trace elements. A case study. Atmospheric Environment (1967), 23(1), 107-114.

Pacyna, J. M., Pacyna, E. G., \& Aas, W. (2009). Changes of emissions and atmospheric deposition of mercury, lead, and cadmium. Atmospheric Environment, 43(1), 117-127.

Pascaud, A., Sauvage, S., Coddeville, P., Nicolas, M., Croisé, L., Mezdour, A., \& Probst, A. (2016). Contrasted spatial and longterm trends in precipitation chemistry and deposition fluxes at rural stations in France. Atmospheric Environment, 146, $28-43$.

Peres-Neto, P., Legendre, P., Dray, S., \& Borcard, D. (2006). Variation partitioning of species data matrices: Estimation and comparison of fractions. Ecology, 87, 2614-2625.

R Core Team. (2013). R: A language and environment for statistical computing. R Foundation for Statistical Computing, Vienna, Austria. http://www.R-project.org/

Rajsic, S., Mijić, Z., Tasic, M., Radenković, M., \& Joksić, J. (2008). Evaluation of the levels and sources of trace elements in urban particulate matter. Environmental Chemistry Letters, 6, 95-100.

Rico, A., Van den Brink, P. J., Leitner, P., Graf, W., \& Focks, A. (2016). Relative influence of chemical and non-chemical stressors on invertebrate communities: A case study in the Danube River. Science of The Total Environment, 571, 1370-1382.

Savchuk, O. P. (2018). Large-scale nutrient dynamics in the Baltic Sea, 1970-2016. Frontiers in Marine Science, 5(95), 1-20.

Schröder, W., Nickel, S., Schonrock, S., Meyer, M., Wosniok, W., Harmens, H., \& Zechmeister, H. G. (2016). Spatially valid data of atmospheric deposition of heavy metals and nitrogen derived by moss surveys for pollution risk assessments of ecosystems. Environmental Science and Pollution Research International, 23(11), 10457-10476.

Schröder, W., Pesch, R., Schönrock, S., Harmens, H., Mills, G., \& Fagerli, H. (2014). Mapping correlations between nitrogen concentrations in atmospheric deposition and mosses for natural landscapes in Europe. Ecological Indicators, 36, 563-571.

Sen, P. K. (1968). Estimates of the regression coefficient based on Kendall's Tau. Journal of the American Statistical Association, 63(324), 1379-1389. https://doi.org/10.1080/ 01621459.1968 .10480934

Stigebrandt, A., Rahm, L., Viktorsson, L., Ödalen, M., Hall, P., \& Liljebladh, B. (2013). A new phosphorus paradigm for the Baltic Proper. Ambio, 43, 634-643.

Suvarapu, L., \& Baek, S. O. (2017). Determination of heavy metals in the ambient atmosphere: A review. Toxicology and Industrial Health, 33(1), 79-96.

Tørseth, K., Aas, W., Breivik, K., Fjæraa, A. M., Fiebig, M., Hjellbrekke, A. G., \& Yttri, K. E. (2012). Introduction to the European Monitoring and Evaluation Programme (EMEP) and observed atmospheric composition change during 1972-2009. Atmospheric Chemistry and Physics, 12(12), 5447-5481. https://doi.org/10.5194/ acp-12-5447-2012
UBA. (2018). Impacts of heavy metal emission on air quality and ecosystems across Germany-Sources, transport, deposition and potential hazards, part 1: Assessment of the atmospheric heavy metal deposition to terrestrial ecosystems in Germany ((UBA-FB) 002635/E). DessauRoßlau, Germany, 92 pages.

UNECE. (1979). Convention on long-range transboundary air pollution. United Nations Economic Commission for Europe.

UNEP. (2013). Global Mercury Assessment 2013: Sources, emissions, releases and environmental transport. Geneva, Switzerland, 44 pages.

van der Swaluw, E., Asman, W. A. H., van Jaarsveld, H., \& Hoogerbrugge, R. (2011). Wet deposition of ammonium, nitrate and sulfate in the Netherlands over the period 19922008. Atmospheric Environment, 45(23), 3819-3826.

Vet, R., Artz, R. S., Carou, S., Shaw, M., Ro, C. -U., Aas, W., \& Reid, N. W. (2014). A global assessment of precipitation chemistry and deposition of sulfur, nitrogen, sea salt, base cations, organic acids, acidity and $\mathrm{pH}$, and phosphorus. Atmospheric Environment, 93, 3-100.

Viana, M., Hammingh, P., Colette, A., Querol, X., Degraeuwe, B., Vlieger, I., \& d., \& van Aardenne, J. (2014). Impact of maritime transport emissions on coastal air quality in Europe. Atmospheric Environment, 90, 96-105.

Vignati, E., Facchini, M. C., Rinaldi, M., Scannell, C., Ceburnis, D., Sciare, J., \& O'Dowd, C. D. (2010). Global scale emission and distribution of sea-spray aerosol: Sea-salt and organic enrichment. Atmospheric Environment, 44(5), 670-677.

Wagner, S., Angenendt, E., Beletskaya, O., \& Zeddies, J. (2017). Assessing ammonia emission abatement measures in agriculture: Farmers' costs and society's benefits-A case study for Lower Saxony, Germany. Agricultural Systems, 157, 70-80.

Waldner, P., Marchetto, A., Thimonier, A., Schmitt, M., Rogora, M., Granke, O., \& Lorenz, M. (2014). Detection of temporal trends in atmospheric deposition of inorganic nitrogen and sulphate to forests in Europe. Atmospheric Environment, 95, 363-374.

Wang, Y., Yu, W., Pan, Y., \& Wu, D. (2012). Acid neutralization of precipitation in Northern China. Journal of the Air \& Waste Management Association, 62(2), 204-211.

Wiederhold, J. G., Biester, H., Gerloff, A. -L., Hahn, J., \& Duester, L. (2020). Mercury contamination in German rivers: Historical trends and current situation, EGU General Assembly 2020, Online, 4-8 May 2020, EGU20209735. https://doi.org/10.5194/egusphere-egu2020-9735

Zhang, Y., Mathur, R., Bash, J. O., Hogrefe, C., Xing, J., \& Roselle, S. J. (2018). Long-term trends in total inorganic nitrogen and sulfur deposition in the U.S. from 1990 to 2010. Atmospheric Chemistry and Physics, 18(12), 9091-9106.

Zobrist, J., Schoenenberger, U., Figura, S., \& Hug, S. J. (2018). Long-term trends in Swiss rivers sampled continuously over 39 years reflect changes in geochemical processes and pollution. Environmental Science and Pollution Research, 25, 1-22.

Publisher's Note Springer Nature remains neutral with regard to jurisdictional claims in published maps and institutional affiliations. 